\title{
Firm Investment and Monetary Policy Transmission in the Euro Area
}

\author{
Jean Bernard Chatelain, Andrea Generale, Ignacio Hernando, \\ Ulf von Kalckreuth, Philip Vermeulen*
}

14 January 2002

\begin{abstract}
We present a comparable set of results on the monetary transmission channels on firm investment for the four largest euro-area countries (Germany, France, Italy and Spain). With particularly rich micro datasets for each country containing over 215,000 observations from 1985 to 1999, we explore what can be learned about the interest channel and the broad credit channel. For each of those countries, we estimate neo-classical investment relationships, explaining investment by its user cost, sales and cash flow. We find investment to be sensitive to user cost changes in all those four countries. This implies an operative interest channel in these euro-area countries. We also find investment in all countries to be quite sensitive to cash flow movements. However, only in Italy do smaller firms react more to cash flow movements than large firms, implying that a broad credit channel might not be equally pervasive in all countries.
\end{abstract}

JEL Classification numbers: E22, E50

Keywords: investment, monetary transmission, user cost of capital

\footnotetext{
* Banque de France; E-mail: jean-bernard.chatelain@banque-france.fr; Banca d'Italia; E-mail: generale.andrea@insedia.interbusiness.it; Banco de España; E-mail: hernando@bde.es; Deutsche Bundesbank; E-mail: ulf.von-kalckreuth@bundesbank.de; European Central Bank: E-mail: philip.vermeulen@ecb.int. This paper represents the authors' personal opinions and does not necessarily reflect the views of the institutions they are affiliated to. We would like to thank the members of the Eurosystem's Monetary Transmission Network and the participants of the monetary economics workshop at the NBER Summer Institute 2001 for helpful discussions and feedback, and especially Daniele Terlizzese for his very helpful comments.
} 


\title{
Firm Investment and Monetary Policy Transmission in the Euro Area
}

\author{
Jean Bernard Chatelain, Andrea Generale, Ignacio Hernando, \\ Ulf von Kalckreuth, Philip Vermeulen
}

\section{Introduction}

Monetary policy is generally thought to be able to affect business investment through multiple channels. First, a traditional interest-rate channel is identified, whereby changes in market interest rates imply changes in the cost of capital, which in turn affect investment. However, the difficulties of using aggregate data to find clear evidence of this channel are well known. Second, changes in market interest rates affect the net cash flow (i.e. cash flow after interest payments) available to a firm. Given imperfect capital markets, the availability of net cash flow will have an effect on investment. This is generally referred to as the broad credit channel.

This paper provides an investigation of those two channels based on results from a unique comparative study of the four largest euro-area countries. ${ }^{1}$ Using rich firm databases for each country, standardised regressions were run to make comparison across countries feasible. Although, for confidentiality reasons, individual data could not be pooled - making formal statistical testing impossible - the standardisation of the analysis should still allow asymmetries in the working of the above channels to be detected. In particular, reliance on firm data should make it possible to identify whether there are differences in the behaviour of firms with otherwise similar characteristics. This has a distinct advantage over the inference based on aggregate data in which "true" differences in behaviour are potentially confounded by differences due to composition of the firms in the aggregate.

The rest of the paper is structured as follows. In section 2 we motivate the analysis and spell out the relevant questions that can be answered by comparing the results across countries. In section 3 we describe the theoretical framework. In section 4 we present our data. In section 5 we present the regression results. In section 6 we test whether a broad credit channel is operative in the euro area. In section 7 we investigate the link between monetary policy, user cost and cash flow.

\footnotetext{
${ }^{1}$ Mojon, Smets and Vermeulen (2001) investigate the elasticity of investment with respect to its user cost using industry data on the same four countries. The MTN project has led to a number of complementary companion papers on investment and monetary policy: Butzen, Fuss and Vermeulen (2001), Chatelain and Tiomo (2001), Gaiotti and Generale (2001), von Kalckreuth (2001), Lunneman and Mathä (2001) and Valderrama (2001).
} 


\section{Motivation of the analysis}

Since the beginning of monetary union in Europe, a large body of empirical analysis has been devoted to the transmission mechanism of monetary policy. These analyses are usually justified by the observation that a common monetary policy affects economies characterised by a high degree of heterogeneity.

This paper is a contribution to the discussion of monetary policy transmission in the euro area; it focuses on the four major euro-area countries by using data collected at the national level. Our perspective is at once wider and narrower than the one motivating previous research. It is narrower in that we limit our attention to a specific channel of monetary policy, firms' investment spending. It is wider in that, by using micro data, we try to take into account the relevance of firms' balance-sheet conditions in the transmission of monetary policy. The contribution of the paper consists mainly in an assessment of the main determinants of investment spending in each of the countries.

Interest in the transmission mechanism is motivated by a variety of reasons that also can have policy implications. First, for a careful assessment of the monetary stance in the area, it is important to know if the pure interest channel is the only channel at work. If agents' financial conditions are shown to be important, then knowing these conditions proves to be important for the policy maker; at the same time this knowledge helps to better forecast the likely effects of a monetary policy decision.

As it is well known, the main channels of monetary policy transmission have been thoroughly examined mainly using macro information (see the survey in Guiso, Kashyap, Panetta and Terlizzese, 1999). These kind of analyses have, on the one hand enabled regularities and differences across the countries of the euro area to be uncovered; on the other hand, they have proved to be limited in many respects. First of all, it is known that aggregation can blur the differences in the transmission of monetary policy and impede the identification of important parts of the transmission mechanism. Hence, recourse to micro data is often motivated in the literature by the recognition of the limits of aggregate studies. In their U.S. study on the relationship between investment spending and the user cost of capital, Chirinko, Fazzari and Meyer (1999) motivate the use of micro data by the very fact that studies at the aggregate level often fail to find an economically significant relationship between these two variables. As the authors note, this failure could have been due "to biased estimates due to problems of simultaneity, capital market frictions, or firm heterogeneity that may be better addressed with micro data".

Moreover, micro data are also needed because of the "extensive variation [in micro data that] will likely provide better instruments [for instrumental variable estimation] than can 
be obtained at the aggregate level." The motivation for employing micro data can be generally ascribed to the advantages of panel data estimation versus time series estimation, often recognised in the econometric literature. "By utilising information on both the intertemporal dynamics and the individuality of entities being investigated, one is better able to control in a more natural way for the effects of missing or unobserved variables" (Hsiao, 1995). Moreover, in our analysis on the determinants of investment, the use of micro data allows firm-level measures of the user cost, sales and cash flow, thus taking into account the fact that the transmission of monetary impulses occurs at the firm level.

In fact, as is well known and indeed very well explained by Chirinko, Fazzari and Meyer (1999), one of the difficulties found in the empirical analysis of the relationship between investment and the user cost is that these estimates usually turn out to be very low. They report that this may be due to simultaneity bias, arguing that "investment comprises a volatile component of aggregate demand, positively correlated with the business cycle, and business cycle movements correlate with interest rates. Positive investment shocks, for example, can cause positive movements in output and the demand for credit that affect the required rates of return on debt and equity. Conventional wisdom suggests that simultaneity between investment shocks and interest rates biases the user cost elasticity towards zero." In this respect, the cross-sectional variation coming from the tax component in the user cost variable that we use in the estimation can be regarded as an exogenous source of variation, thus allowing us to identify the effects of the cost of capital on investment. Moreover, simultaneity problems are reduced by IV or GMM estimation. Hence, the combination of instrumental variable estimation and the exogenous source of variability ensured by tax variations should improve our ability to properly identify user cost effects. ${ }^{2}$

Finally, it is worth quoting Hsiao (1995) again, who says that "longitudinal data allow a researcher to analyse a number of important economic questions that cannot be addressed using cross-sectional or time-series data sets." This is the case if one wants to precisely identify the existence of a broad credit channel, i.e. the second channel of monetary transmission.

The literature on the broad credit channel of monetary policy has emphasised the relevance of information asymmetries in the transmission of monetary policy. In particular, the difficulty faced by lenders in monitoring the projects of "opaque" firms implies that firms' financial conditions are important for the availability and cost of external finance.

${ }^{2}$ It has to be clarified that we are not pursuing the strategy of research adopted by Cummins et al. $(1994,1996)$ that stretched this line of identification as far as to measure investment elasticities to the user cost in years of major tax reform. At any rate, it is important for us to be sure of having a sufficient amount of variability in the data due to this tax component. 
The result that, given information asymmetries, the Modigliani-Miller theorem does not hold implies also that firms that are likely to be more exposed to problems of asymmetric information might react more to a monetary tightening (Gilchrist and Zakrajsek, 1995). Analysing the reaction to a common shock of groups of firms characterised by weaker balance sheets and comparing it to other firms that are in a better financial position solves the identification problems encountered with the use of macro-data. In particular, whereas aggregate data are able to identify the relevance of the interest-rate channel, it is only by analysing the different behaviour of different groups of agent that we are able to robustly identify the presence of a broad credit channel.

There are also drawbacks in using micro data. They mainly consist in the difficulty of recovering aggregate effects from micro estimations. This is mainly caused by the fact that usually shorter time periods are available in panels, thus implying that variation in the monetary policy stance can be more limited than with time series data, and that samples are often biased towards specific types of firms. We are aware of these difficulties: as documented in the data set description, we are confident that the sample chosen is quite representative of the firms' characteristics in each country; moreover, in comparison to other contributions on panel analysis, we have panels that are quite long. A thorough comparison of results coming from macro and micro evidence is outside the scope of this paper.

After this overview, we want to give a picture of the main real and financial characteristics of these countries. The observation of significant heterogeneities has often motivated the analysis of the transmission mechanism with the aim of uncovering the presence of asymmetries in the reaction observed across countries. In effect, a high degree of heterogeneity seems to characterise these economies in particular with regard to firms' financial structure, the availability of external funds and the industrial structure. Table 1a illustrates some of these differences.

On the real side, the distribution of firms by size turns out to be quite dissimilar: in Germany only 48 per cent of total turnover of non-financial firms pertained to firms with less than 250 employees, whereas, at the other extreme, in Italy such firms accounted for 71 per cent.

As to financial structure, firms differ markedly with respect to both the availability of external funds and the composition of their financial debt. Data collected by the Monetary Transmission Network show, for example, that reliance on bank credit is highest in Italy, partly reflecting the more limited role of equity in firm financing; it is much more limited in the other countries. Spain, a country in an intermediate position as to dependence on 
bank debt, also shows a high share of equity financing, in terms of both capital's and reserves' share of firms' total liabilities and of stock market capitalisation as a percentage of GDP. More importantly, for the transmission of monetary policy impulses, the share of short-term debt differs markedly across countries, with higher values in Italy and Spain. Looking at recent transaction data, flows in bank loans have substantially exceeded flows in shares and other equity in Germany, Italy and Spain. France is the exception to this pattern. It seems to be the country with a lower dependence on bank debt, corroborated by its relatively high stock market capitalisation.

One obvious question that arises when looking at cross-country differences, then, is whether these broad institutional characteristics are conducive to a different reaction to monetary policy. It has to be clarified that the research strategy adopted in this paper is only able to address partially the issue of asymmetries across countries. We are in fact mainly interested in documenting the importance of the different transmission mechanisms in each country. Our research strategy is the following: we first estimate investment equations for each country, giving us the sensitivity of investment to its main determinants: the user cost, sales and cash flow. This permits an assessment of the relative importance of the different channels in each country. Moreover, by calculating the response of investment determinants to monetary policy we obtain a measure of the elasticity of investment to monetary policy. The comparison of the results obtained across countries is needed to understand how the transmission of monetary impulses takes place at the country level. Moreover, it gives a rough indication of the existence or absence of asymmetries. For confidentiality reasons, cross-country comparisons cannot are not performed on a pooled data set, thus impeding a formal test on the significance of the differences.

We believe, though, that examining the main channels of transmission in each country is only a first step in assessing the relevance of asymmetries. Consider the case of the broad credit channel: if financial variables prove to be important in a given country, then there is evidence that differences in access to financial markets in this country play a role. But, at the country-by-country analysis stage, finding larger effects of financial variables in one country does not mean that a broad credit channel is at work. One way to partly address this issue consists in performing a test of the differences in reaction to investment determinants for firms that are more likely to be subject to information asymmetries. The detection of significant differences within each country permits us to highlight how widespread heterogeneous behaviour is in the countries we examine. Future research in the field should seek to carefully assess the quantitative importance of the eventual differences found and try to trace the observed differences back to the presence of heterogeneity in behaviour or in the composition of the firms in the economy. Some steps in this direc- 
tion are taken by the various country-specific investigations carried out with the MTN, namely Butzen, Fuss and Vermeulen (2001), Chatelain and Tiomo (2001), Gaiotti and Generale (2001), von Kalckreuth (2001), Lünneman and Mathä (2001) and Valderrama (2001).

Table 1a: Financial structure, capital markets and real indicators in the euro area

\begin{tabular}{|c|c|c|c|c|}
\hline & Germany & France & Italy & Spain \\
\hline \multicolumn{5}{|c|}{$\begin{array}{l}\text { Financial structure of manufacturing firms (1) } \\
\text { as a \% of total liabilities; } 1997\end{array}$} \\
\hline Bank credit & 6.2 & 7.2 & 21.2 & 11.0 \\
\hline \multicolumn{5}{|l|}{ Of which: } \\
\hline Maturity of less than 1 year & 3.7 & 3.3 & 14.3 & 6.6 \\
\hline Maturity of more than 1 year & 2.5 & 3.9 & 6.9 & 4.4 \\
\hline Bonds & 0.2 & 1.9 & 0.9 & 0.1 \\
\hline Capital and reserves & 32.9 & 38.0 & 28.1 & 45.7 \\
\hline \multicolumn{5}{|c|}{$\begin{array}{c}\text { External financing transactions of non-financial corporations (2) } \\
\text { as a \% of nominal GDP; Average 1996-1999 }\end{array}$} \\
\hline Loans & 4.5 & 2.0 & 2.0 & 5.4 \\
\hline Securities other than shares & -0.1 & 0.6 & 0.0 & -0.1 \\
\hline Shares and other equity & 1.5 & 3.4 & 1.3 & 2.7 \\
\hline Other liabilities & 0.8 & 0.7 & 1.2 & 6.3 \\
\hline \multicolumn{5}{|c|}{$\begin{array}{c}\text { Capital markets (2) } \\
\text { As a \% of nominal GDP; } 1997\end{array}$} \\
\hline $\begin{array}{l}\text { Total financial liabilities of non-financial } \\
\text { firms }\end{array}$ & 128.8 & 268.4 & 135.0 & 209.6 \\
\hline Stock-market capitalisation & 39.9 & 49.5 & 30.6 & 56.2 \\
\hline Bonds of non-financial firms & 0.1 &. & 1.6 & 2.7 \\
\hline \multicolumn{5}{|c|}{$\begin{array}{ll} & \text { Real indicators } \\
\end{array}$} \\
\hline Investment/GDP \% average 1996-2000 (3) & 22.2 & 19.0 & 19.4 & 23.3 \\
\hline $\begin{array}{l}\text { Share of total non-financial firms turnover } \\
\text { attributable to firms with less than } 250 \text { em- } \\
\text { ployees } 1997 \text { (2) }\end{array}$ & 48.0 & 56.0 & 71.0 & 62.0 \\
\hline
\end{tabular}

(1) Source: BACH data set (European Commission).

(2) Source: Eurostat.

(3) Source: OECD and Eurostat.

\section{The theoretical framework}

The investment model we use is derived from the neo-classical demand for capital. It has recently been estimated using panel data by, among others, Bond, Elston, Mairesse and Mulkay (1997), Chirinko, Fazzari and Meyer (1999), and Hall, Mairesse and Mulkay (1999, 2001). Abstracting from irreversibility, uncertainty, delivery lags and adjustment costs, the first order condition for a firm's optimisation problem leads to the equality between the marginal product of capital and the user cost of capital $U C_{i t}$ :

$F_{K}\left(K_{i t}, L_{i t}\right)=U C_{i t}$,

where i stands for firm, and t stands for time. 
Following Auerbach (1983) and Hayashi (2000), we obtain a weighted-average definition of the user cost of capital where the cost of debt and equity are weighted with their respective share of the total liabilities of the firm. We use the accounting proportions of debt and equity which matters for taxation:

$$
U C_{i t}=\frac{p_{s t}{ }^{I}}{p_{s t}} \frac{\left(1-i t c_{t}-\tau_{t} z_{s}\right)}{\left(1-\tau_{t}\right)}\left[A I_{i t}\left(\frac{D_{i t}}{D_{i t}+E_{i t}}\right)\left(1-\tau_{t}\right)+\left(L D_{t}\right)\left(\frac{E_{i t}}{D_{i t}+E_{i t}}\right)-\left(1-\delta_{s}\right) \frac{\Delta P_{s t+1}{ }^{I}}{P^{I}{ }_{s t}}+\delta_{s}\right]
$$

where $s$ is the sector-specific index, $p_{s t}$ the price of final goods, $p_{s t}^{I}$ the price of capital goods of sector $\mathrm{s} ; \tau_{t}$ the corporate income tax rate, against which interest payments and depreciation are assumed to be deductible, $z$ the present value of depreciation allowances, and itc the investment tax credit. AI is the apparent interest rate, measured as interest payment over gross debt, LD the long-term debt rate used as a proxy for the opportunity cost of equity, E the book value of equity, and $\delta_{s}$ the industry-specific rate of economic depreciation.

In contrast to the King and Fullerton (1984) approach, as used by Harhoff and Ramb (2001) and von Kalckreuth (2001), this user cost of capital does not take into account the differences for dividends and retained earnings for households income tax and the distinction between different capital goods for the computation of the net present value of depreciation allowances. ${ }^{3}$

Following Eisner and Nadiri (1968), we parameterise the production function by a constant elasticity of the substitution production function:

$$
F\left(K_{i t}, L_{i t}\right)=T F P_{i} A_{t}\left[\beta_{i} L_{i t}^{\frac{\sigma-1}{\sigma}}+\alpha_{i} K_{i t}^{\frac{\sigma-1}{\sigma}}\right]^{\frac{\sigma}{\sigma-1} v}, \quad \alpha_{i}+\beta_{i}=1,
$$

where $\sigma$ is the elasticity of substitution between capital and labour, $V$ represents returns to scale, $T F P_{i} A_{t}$ is total factor productivity which we assume to have two components: a firm-specific one and a year-specific one. Substituting the marginal productivity of capital in equation (1) yields:

$$
\log K_{i t}=\theta \log Y_{i t}-\sigma \log U C_{i t}+\log H_{i t},
$$

where $\theta=\left(\sigma+\frac{1-\sigma}{v}\right)$ and $H_{t}=\left(T F P_{i} A_{t}\right)^{\frac{\sigma-1}{v}} \cdot\left(v \alpha_{i}\right)^{\sigma}$.

\footnotetext{
${ }^{3}$ The user cost variable in von Kalckreuth (2001) models additional details of the German tax code. However, results in that paper are qualitatively similar to the results presented here.
} 
$Y_{i t}$ represents sales. The variable $H_{i t}$ depends on the time-varying term $A_{t}$ and the firmspecific term $T F P_{i}$. The elasticity of capital to sales is unity $(\theta=1)$, if the production function has constant returns to scale $(v=1)$, or if its elasticity of substitution is unity $(\sigma=1)$, that is, in the Cobb-Douglas case.

We do not assume that (4) always holds; instead, we assume that the firm changes its capital stock in the direction of a long-run target value $\mathrm{K}^{*}$ :

$\log K^{*}{ }_{i t}=\theta \log Y_{i t}-\sigma \log U C_{i t}+\log H_{i t}$,

The long-run target value for capital, $\mathrm{K}^{*}$, is not observable, which means that to go from (6) to an empirical specification, we need to specify an adjustment process. We specify an auto-regressive distributed lag model $\left(\operatorname{ADL}(3,3) .{ }^{4}\right)$ :

$$
\begin{aligned}
& k_{i t}=\omega_{1} k_{i t-1}+\omega_{2} k_{i t-2}+\omega_{3} k_{i t-3}+\theta_{0} y_{i t}+\theta_{1} y_{i t-1}+\theta_{2} y_{i t-2}+\theta_{3} y_{i t-3}-\sigma_{0} u c_{i t}- \\
& \sigma_{1} u c_{i t-1}-\sigma_{2} u c_{i t-2}-\sigma_{3} u c_{i t-3}+\phi_{0} h_{i t}+\phi_{1} h_{i t-1}+\phi_{2} h_{i t-2}+\phi_{3} h_{i t-3}
\end{aligned}
$$

where we have used lower case letters to refer to the corresponding level variables in logs. In the long run, the effects of a permanent change in the explanatory variables in (7) are assumed to add up to the effect given by (6). This implies that we can identify the longrun elasticities of sales and user cost. The long-run user cost elasticity with respect to the stock of capital is given by $\sigma=\left(\sigma_{0}+\sigma_{1}+\sigma_{2}+\sigma_{3}\right) /\left(1-\omega_{1}-\omega_{2}-\omega_{3}\right)$ and the longrun sales elasticity with respect to the stock of capital is $\theta=\left(\theta_{0}+\theta_{1}+\theta_{2}+\theta_{3}\right) /\left(1-\omega_{1}-\omega_{2}-\omega_{3}\right)$. At this stage, there are two possible strategies. The first one transforms the ADL model into an error-correction model (Hall, Mairesse and Mulkay, 1999). The second strategy consists of first differencing the ADL model (Chirinko, Fazzari and Meyer, 1999). The possibility of firm-specific effects not only on the level of productivity but also on its growth rate may justify this second strategy on panel data. For simplicity, we will only use the second strategy. We leave the possible comparison between the two approaches to companion country papers of the Monetary Transmission Network. First-differencing and using the approximation $\log K_{t}-\log K_{t-1}=I_{t} / K_{t-1}-\delta$, and replacing productivity by time dummies, a firmspecific effect $f$ and a random term $\varepsilon$ yields:

$$
\begin{aligned}
& \frac{I_{i t}}{K_{i t-1}}=f_{i}+\omega_{1} \frac{I_{i t-1}}{K_{i t-2}}+\omega_{2} \frac{I_{i t-2}}{K_{i t-3}}+\omega_{3} \frac{I_{i t-3}}{K_{i t-4}}+\theta_{0} \Delta y_{i t}+\theta_{1} \Delta y_{i t-1}+\theta_{2} \Delta y_{i t-2}+\theta_{3} \Delta y_{i t-3} \\
& -\sigma_{0} \Delta u c_{i t}-\sigma_{1} \Delta u c_{i t-1}-\sigma_{2} \Delta u c_{i t-2}-\sigma_{3} \Delta u c_{i t-3}+\text { time dummies }+\varepsilon_{i t}
\end{aligned}
$$

\footnotetext{
${ }^{4}$ Hall, Mairesse and Mulkay (1999) consider an $\operatorname{ADL}(2,2)$ but do not include the user cost of capital.
} 
We estimate this equation (8). In addition, to be in line with the literature, we also estimate an extension of equation (8). It has been argued frequently that a measure of liquidity should enter the model to account for access to internal funds that might affect investment in the presence of financing constraints. Liquidity is usually measured as cash flow (CF). For comparison with the existing literature, and to avoid unit problems, cash flow enters relative to the existing capital stock.

$$
\begin{aligned}
& \frac{I_{i t}}{K_{i t-1}}=f_{i}+\omega_{1} \frac{I_{i t-1}}{K_{i t-2}}+\omega_{2} \frac{I_{i t-2}}{K_{i t-3}}+\omega_{3} \frac{I_{i t-3}}{K_{i t-4}}+\theta_{0} \Delta y_{i t}+\theta_{1} \Delta y_{i t-1}+\theta_{2} \Delta y_{i t-2}+\theta_{3} \Delta y_{i t-3} \\
& -\sigma_{0} \Delta u c_{i t}-\sigma_{1} \Delta u c_{i t-1}-\sigma_{2} \Delta u c_{i t-2}-\sigma_{3} \Delta u c_{i t-3}+\text { time dummies } \\
& +\phi_{0} \frac{C F_{i t}}{p_{s t}^{I} K_{i, t-1}}+\phi_{1} \frac{C F_{i, t-1}}{p_{s, t-1}^{I} K_{i, t-2}}+\phi_{2} \frac{C F_{i, t-2}}{p_{s, t-2}^{I} K_{i, t-3}}+\phi_{3} \frac{C F_{i, t-3}}{p_{s, t-3}^{I} K_{i, t-4}}+\varepsilon_{i t}
\end{aligned}
$$

The parameters $\phi$ measure the sensitivity of investment with respect to cash flow movements.

\section{Data set description}

In this section an overview is given of the individual country data used in the regressions. Definitions of the variables used were made as comparable as possible between the different countries. National data sets do differ in many respects. First of all, the way in which data are collected in each country is not the same. The fact that the prerequisites for entering in the sample are different implies that the representativeness of each sample differs across countries. In general, the samples are skewed towards larger firms. Moreover, every sample is unbalanced and differs in the degree in which firms enter and leave the sample.

In Germany, the Bundesbank's corporate balance sheet database constitutes the largest collection of accounting data for German non-financial firms; ${ }^{5}$ the collection of financial statements originated from the Bundesbank's function of performing credit assessments within the scope of its rediscount operations. On the whole, every year around 70,000 annual accounts were collected, on a strictly confidential basis, by the Bundesbank's branch offices. The German data set is probably skewed towards large firms since, according to the turnover tax statistics, these firms represented roughly $75 \%$ of the total turnover of the West German manufacturing sector, albeit only $8 \%$ of the total number of firms.

In France, the data source consists of compulsory accounting tax forms ${ }^{6}$ and of additional information taken from surveys collected by the Banque de France (the database "Centrale

\footnotetext{
${ }^{5}$ A detailed description is contained in Deutsche Bundesbank (1998); see also Friderichs and Sauvé (1999) and Stöss (2001).

${ }^{6}$ They are collected by the Banque de France in the database FIBEN.
} 
des Bilans"'). Since these data are collected only from firms who are willing to provide them, French data are likewise skewed towards large firms. ${ }^{7}$

Data for Italy are drawn from the Italian Company Accounts Data Service (Centrale dei bilanci), that, considering the whole period 1983-1999 and all non-financial enterprises, contains around 692,000 observations, for around 40,000 firms per year. Also for Italy there exists a bias towards large firms, since firms are not randomly drawn: in fact, the prerequisite for entering the sample is that each firm has to be indebted with a bank; moreover, preference is given to firms with multiple lending relationships. ${ }^{8}$

The Spanish data were obtained from the Central Balance Sheet Office of the Banco de España (CBBE), and, in particular, from the Annual Central Balance Sheet Database (CBA); this database is compiled through the voluntary collaboration of non-financial firms and is edited by means of contacts with them. Thus, it only covers those firms that voluntarily complete the questionnaire and is biased towards large and manufacturing firms. The initial database included 115,980 observations corresponding to 22,014 firms over the 1983-1999 period. In 1994, its coverage of the non-financial firms sector, in terms of value added, was around $35 \%{ }^{9}$

For the econometric analysis, a smaller data set was used in each country. The loss in observations was due to the following reasons. First, we limited the analysis to the manufacturing sector, for which data for the calculation of the capital stock at replacement cost appeared to be more reliable. Second, applying the perpetual inventory formula and using investment over lagged capital as a regressor meant dropping the first year-firm observations. Third, trimming (see appendix) and selecting firms which are consecutively present in the sample at least during five years in order to use a sufficient number of lags as explanatory variables led to the final sample in each country.

Some specificities in each country are worth mentioning: for the German sample, which originally contained unincorporated businesses, we have excluded sole proprietorships and unincorporated partnerships because of differences in accounting rules; ${ }^{10}$ this permits a higher degree of comparability with the other countries. Again for reasons of comparability, we only consider West German manufacturing firms, and we confine ourselves to the

\footnotetext{
${ }^{7}$ Small firms of less than 20 employees are underrepresented. No statistical sampling procedure has been used to correct this bias.

${ }^{8}$ Moreover, since the information collected is meant to be a service for banks in deciding their credit policies, the sample is biased towards firms that are creditworthy.

${ }^{9}$ For a more detailed description of this database, see Banco de España (2000).

${ }^{10}$ All publicly-owned enterprises were discarded, too, as they might not be profit-oriented.
} 
years 1988 - 1997. ${ }^{11}$ In Italy, we discarded the firms for which information to construct the user cost (i. e. fiscal data) was not available.

In general, we ended up with samples that, though skewed towards larger firms, are still representative of the manufacturing sector of each economy. Moreover, very often, balance sheet data only contain large and listed firms, whereas in our sample the median number of employees is 118 in Germany, 31 in Italy, 50 in Spain, and 55 in France. This means also that the data set covers unlisted companies, which are probably the best candidates to test for balance-sheet effects, quite well; listed companies represent less than 4 per cent of the sample in Spain, less than 2 in Italy, and less than 6 in Germany and France. Moreover, firms are spread throughout the sectors of manufacturing ${ }^{12}$.

In each country, the period covered by the samples used in estimation is 1985-1999, with the exception of Germany for which the time period available for estimation is 1988-1997. The total number of observations and the number of years available are comparable to or higher than those of the sample used by Chirinko et al. (1999) for US firms. ${ }^{13}$ For the European samples, coverage, calculated on the total number of employees in the manufacturing sector, ranges from 19 per cent for Spain to 45 per cent for Germany ${ }^{14}$.

Table $1 \mathrm{~b}$ shows the investment-capital ratio, real sales growth, real user cost growth, cash flow on capital, and log of the user cost level in each country. Overall, as is usually the case with panel data, there is a wide dispersion of the variables used in all countries. The mean of the investment capital ratio is higher in Germany (0.181) and Spain (0.186) than in France (0.122) and Italy (0.124). The high mean of the investment capital ratio in Spain is matched by a high average sales growth (0.043). This contrasts with Germany where average sales growth is the lowest of all four countries (0.021). Average user cost growth over the period differs quite substantially across the four countries. In Germany user costs increased on average by 2.5 percent, while in Italy they decreased on average by 1.2 percent. On average, the ratio of cash flow over capital is higher in Spain (0.37) and France (0.33) than in Germany (0.276) and Italy (0.196).

\footnotetext{
${ }^{11}$ Earlier years are affected by the radical regulatory changes in accounting introduced in 1985, triggered by an EU directive on the harmonisation of financial statements.

${ }^{12}$ The wider time dimension of these databases makes them preferable to other data sets containing a larger number of firms, which are often available in the countries examined. For example, in Italy the CERVED database contains information on balance sheet and profit and loss accounts of all firms excluding sole proprietorships (roughly 500,000 firms), but the first year available is 1993 .

${ }^{13}$ They had a sample of 26,071 observations ranging from 1981 to 1991 with a total number of firms of 4,095.

${ }^{14}$ For Germany, coverage calculated over total turnover of the sector in 1996 was $38.4 \%$ percent of the turnover of the whole sector. The analysis of the distribution by size indicates that a large portion of small and medium sized enterprises that make up the core of West German industry is present in the sample. Moreover, the sample mirrors the West German industrial structure relatively well.
} 


\begin{tabular}{|c|c|c|c|c|c|c|c|c|}
\hline \multicolumn{9}{|c|}{ Table 1b: Summary statistics: complete cleaned data sets } \\
\hline Var & Country & Mean & Std. Dev. & Minimum & $25 \%$ & Median & $75 \%$ & Maximum \\
\hline \multicolumn{9}{|c|}{ It/Kt-1 } \\
\hline & Germany & 0.181 & 0.219 & 0.000 & 0.059 & 0.116 & 0.216 & 2.291 \\
\hline & France & 0.122 & 0.141 & 0.000 & 0.039 & 0.080 & 0.151 & 1.430 \\
\hline & Italy & 0.124 & 0.155 & 0.000 & 0.040 & 0.080 & 0.151 & 3.300 \\
\hline & Spain & 0.186 & 0.217 & -0.033 & 0.049 & 0.117 & 0.240 & 1.560 \\
\hline \multicolumn{9}{|c|}{$? \log \mathrm{St}$} \\
\hline & Germany & 0.021 & 0.158 & -0.596 & -0.058 & 0.021 & 0.107 & 0.828 \\
\hline & France & 0.029 & 0.153 & -1.780 & -0.051 & 0.029 & 0.112 & 1.360 \\
\hline & Italy & 0.034 & 0.196 & -2.400 & -0.060 & 0.035 & 0.131 & 3.000 \\
\hline & Spain & 0.043 & 0.171 & -0.660 & -0.051 & 0.041 & 0.136 & 0.780 \\
\hline \multicolumn{9}{|c|}{$? \log$ Uct } \\
\hline & Germany & 0.025 & 0.110 & -0.356 & -0.044 & 0.025 & 0.091 & 0.422 \\
\hline & France & -0.009 & 0.140 & -0.339 & -0.107 & -0.014 & 0.089 & 0.362 \\
\hline & Italy & -0.012 & 0.263 & -2.100 & -0.150 & -0.008 & 0.126 & 1.700 \\
\hline & Spain & 0.006 & 0.150 & -0.380 & -0.107 & 0.011 & 0.113 & 0.510 \\
\hline \multicolumn{9}{|c|}{ CFt/Kt-1 } \\
\hline & Germany & 0.276 & 0.464 & -1.191 & 0.109 & 0.188 & 0.325 & 9.268 \\
\hline & France & 0.330 & 0.330 & -0.450 & 0.160 & 0.260 & 0.410 & 4.320 \\
\hline & Italy & 0.196 & 0.220 & -1.200 & 0.090 & 0.152 & 0.244 & 4.500 \\
\hline & Spain & 0.370 & 0.469 & -1.100 & 0.126 & 0.256 & 0.471 & 5.000 \\
\hline \multicolumn{9}{|c|}{ Log Uct } \\
\hline & Germany & -1.865 & 0.182 & -2.572 & -1.984 & -1.859 & -1.738 & -1.126 \\
\hline & France & -1.770 & 0.140 & -2.260 & -1.860 & -1.770 & -1.670 & -1.270 \\
\hline & Italy & -1.870 & 0.272 & -3.500 & -2.000 & -1.860 & -1.710 & -0.900 \\
\hline \multirow{2}{*}{\multicolumn{2}{|c|}{ Spain }} & -1.742 & 0.185 & -3.351 & -1.851 & -1.736 & -1.613 & -0.984 \\
\hline & & No. obs. & No. firms & Years & & & & \\
\hline & Germany & 40,362 & 5,876 & 1989-1997 & & & & \\
\hline & France & 61,237 & 6,946 & 1985-1999 & & & & \\
\hline & Italy & 94,523 & 8,019 & 1985-1999 & & & & \\
\hline & Spain & 19,025 & 2,034 & 1985-1999 & & & & \\
\hline
\end{tabular}

\section{Regression results}

In this section we present regression results for the specifications reported in equations (8) and (9). We first present estimation results using the WITHIN estimator. We then present estimation results using the GMM estimator developed by Arellano and Bond (1991).

Table 2 reports the results obtained with the WITHIN estimator. We include a full set of time dummies. These will capture the effect of macro influences on firm-specific investment. We dropped the lagged dependent variable for two reasons. First, it is known that the WITHIN estimator is biased with certainty when lagged dependent variables are present (Nickell, 1981). This bias is due to the correlation of the transformed residual with the transformed lagged dependent variable. Second, in this way we can directly compare our WITHIN estimation results with those obtained for US data by Chirinko, Fazzari and 
Meyer (1999) using a panel of 4,095 manufacturing and non-manufacturing firms from 1981-91 representing 48\% of aggregate US non-residential investment in 1987. (See their Table 2 at page 62 for the WITHIN results.)

Table 2: Models of Investment Demand - 3 lags WITHIN estimates,

Dependent Variable: $\mathbf{I}_{\mathrm{I}, \mathrm{t}} \mathbf{K}_{\mathrm{I}, \mathrm{t}-1}$

\begin{tabular}{|c|c|c|c|c|}
\hline $\begin{array}{l}\text { Explanatory } \\
\text { Variable }\end{array}$ & GERMANY & FRANCE & ITALY & SPAIN \\
\hline$? \log S_{\mathrm{I}, \mathrm{t}}$ & $0.126(0.008)^{* *}$ & $0.107(0.005)^{* *}$ & $0.075(0.004)^{* *}$ & $0.080(0.014)^{* *}$ \\
\hline$? \log \mathrm{S}_{\mathrm{I}, \mathrm{t}-1}$ & $0.121(0.009)^{* *}$ & $0.099(0.005)^{* *}$ & $0.072(0.003)^{* *}$ & $0.077(0.013)^{* *}$ \\
\hline$? \log \mathrm{S}_{\mathrm{I}, \mathrm{t}-2}$ & $0.097(0.097)^{* *}$ & $0.059(0.005)^{* *}$ & $0.048(0.004)^{* *}$ & $0.042(0.013)^{* *}$ \\
\hline$? \log \mathrm{S}_{\mathrm{I}, \mathrm{t}-\mathrm{3}}$ & $0.064(0.008)^{* *}$ & $0.040(0.005)^{* *}$ & $0.031(0.003)^{* *}$ & $0.038(0.012)^{* *}$ \\
\hline $\begin{array}{l}\text { Long-term sales } \\
\text { elasticity }\end{array}$ & $0.407(0.022)^{* *}$ & $0.305(0.011)^{* * *}$ & $0.228(0.010)^{* * *}$ & $0.237(0.033)^{* * *}$ \\
\hline$? \log \mathrm{UC}_{\mathrm{i}, \mathrm{t}}$ & $-0.230(0.013)^{* *}$ & $-0.211(0.007)^{* * *}$ & $-0.144(0.003)^{* * *}$ & $-0.187(0.029)^{* * *}$ \\
\hline$? \log \mathrm{UC}_{\mathrm{i}, \mathrm{t}-1}$ & $-0.213(0.014) * *$ & $-0.110(0.007)^{* *}$ & $-0.095(0.003)^{* * *}$ & $0.024(0.030)$ \\
\hline$? \log \mathrm{UC}_{\mathrm{i}, \mathrm{t}-2}$ & $-0.107(0.013) * *$ & $-0.046(0.007)^{* *}$ & $-0.052(0.003)^{* * *}$ & $0.048(0.030)$ \\
\hline$? \log \mathrm{UC}_{\mathrm{i}, \mathrm{t}-3}$ & $-0.080(0.080)^{* *}$ & $-0.015(0.006)^{*}$ & $-0.020(0.002)^{* *}$ & $0.023(0.026)$ \\
\hline $\begin{array}{l}\text { Long-term user } \\
\text { cost elasticity }\end{array}$ & $-0.630(0.022)^{* * *}$ & $-0.382(0.013) * *$ & $-0.318(0.010)^{* * *}$ & $-0.092(0.064)$ \\
\hline No. of obs. & 22,734 & 33,453 & 62,447 & 8,855 \\
\hline No. of firms & 5,876 & 6,946 & 8,019 & 2,034 \\
\hline
\end{tabular}

* Significant at the $5 \%$ level. ** Significant at the $1 \%$ level. Time dummies are included.

For all countries, sales have a substantial effect in the long run on the capital stock. We obtain long-term sales elasticities ranging from 0.407 in Germany to 0.228 in Italy. Also for all countries, the contemporaneous effect of sales is the largest, ranging from 0.126 in Germany to 0.075 in Italy. All lags of sales growth (up to t-3) have a significant effect on investment. This could be due to many different reasons, including installation lags or adjustment cost. Chirinko et al. (1999) found a rather similar long-run sales elasticity of 0.322 with a contemporaneous effect of 0.120 for the U.S.

For all countries except Spain, also the user cost has a significant effect on the capital stock in the long run. We obtain user cost elasticities ranging from -0.63 in Germany to 0.318 in Italy. ${ }^{15}$ Chirinko et al. (1999) found a long-run user cost elasticity of -0.721 . In every country (including the U.S.), except for Spain, these long-term user cost elasticities are even higher than the long-term sales elasticities. Again, the contemporaneous effect is the largest and past user cost changes are generally significant. This provides evidence against simple sales-accelerator models that only include sales and exclude user costs. It is important to note that even for Spain, although the long-run user cost elasticity (UCE) is not significant, the contemporaneous user cost effect is clearly negative and significant.

15 The sign and dimension of these two effects are similar to those obtained using specifications with a different lag structure and are similar to those reported in the paper by Gaiotti and Generale that employ a data set that contains non-manufacturing Italian firms as well. 
Moreover, in a more parsimonious specification, removing the insignificant lags, the point estimates of the remaining regressors do not significantly change and the long-run user cost elasticity is larger, in absolute value, and significant.

Due to simultaneity between investment and the user cost, the WITHIN estimates might be biased towards zero. This problem, of course, can be generalised to a potential simultaneity between all variables in the regression.

Therefore, we also present the results using the GMM first difference estimator of Arellano-Bond (1991). This time we include the lagged dependent variable. We use as instruments the lagged variables used in the regression from $\mathrm{t}-2$ onwards. The results are in Table 3 .

Table 3: ADL Models of Investment Demand - 3 lags

GMM estimates, Dependent Variable: $\mathbf{I}_{\mathrm{i}, \mathrm{t}, \mathrm{K}} \mathbf{K}_{\mathrm{i}, \mathrm{t}-1}$

\begin{tabular}{|c|c|c|c|c|}
\hline $\begin{array}{l}\text { Explanatory } \\
\text { Variable }\end{array}$ & GERMANY & FRANCE & ITALY & SPAIN \\
\hline $\mathrm{I}_{\mathrm{I}, \mathrm{t}-1} / \mathrm{K}_{\mathrm{i}, \mathrm{t}-2}$ & $0.142(0.017)^{* *}$ & $0.024(0.061)$ & $0.176(0.007)^{* * *}$ & $0.123(0.019)^{* *}$ \\
\hline $\mathrm{I}_{\mathrm{I}, \mathrm{t}-2} / \mathrm{K}_{\mathrm{i}, \mathrm{t}-3}$ & $0.010(0.009)$ & $0.050(0.011)^{*}$ & $0.022(0.005)^{* *}$ & $-0.004(0.014)$ \\
\hline $\mathrm{I}_{\mathrm{I}, \mathrm{t}-3} / \mathrm{K}_{\mathrm{i}, \mathrm{t}-4}$ & $0.008(0.007)$ & $0.029(0.006)^{*}$ & $0.017(0.005)^{* *}$ & $0.001(0.012)$ \\
\hline$\sum \mathrm{I}_{\mathrm{i}, \mathrm{t}-\mathrm{n}} / \mathrm{K}_{\mathrm{i}, \mathrm{t}-\mathrm{n}-1}$ & $0.160(0.026)^{* * *}$ & $0.103(0.031)^{*}$ & $0.215(0.013)^{* * *}$ & $0.120(0.035)^{* *}$ \\
\hline$? \log \mathrm{S}_{\mathrm{i}, \mathrm{t}}$ & $0.162(0.053)^{* *}$ & $0.073(0.035)^{*}$ & $0.117(0.032)^{*}$ & $0.038(0.064)$ \\
\hline$? \log \mathrm{S}_{\mathrm{i}, \mathrm{t}-1}$ & $0.106(0.013) * *$ & $0.086(0.009) *$ & $0.062(0.040)^{* *}$ & $0.041(0.017)^{* *}$ \\
\hline$? \log S_{i, t-2}$ & $0.069(0.011)^{* *}$ & $0.137(0.008)^{*}$ & $0.033(0.005)^{* *}$ & $0.027(0.014)^{*}$ \\
\hline$? \log \mathrm{S}_{\mathrm{i}, \mathrm{t}-3}$ & $0.042(0.010)^{* *}$ & $0.014(0.006)^{*}$ & $0.013(0.005)^{* * *}$ & $0.018(0.012)$ \\
\hline$\sum ? \log \mathrm{S}_{\mathrm{I}, \mathrm{t}-\mathrm{n}}$ & $0.379(0.062) * *$ & $0.310(0.024) *$ & $0.224(0.039) * *$ & $0.124(0.075)^{*}$ \\
\hline $\begin{array}{l}\text { Long-term sales } \\
\text { elasticity }\end{array}$ & $0.452(0.073)^{* *}$ & $0.346(0.036) *$ & $0.286(0.049) * *$ & $0.141(0.085) *$ \\
\hline$? \log \mathrm{UC}_{\mathrm{i}, \mathrm{t}}$ & $-0.286(0.089)^{* *}$ & $-0.055(0.026)^{*}$ & $-0.045(0.016)^{* *}$ & $-0.274(0.135)^{* * *}$ \\
\hline$? \log \mathrm{UC}_{\mathrm{i}, \mathrm{t}-1}$ & $-0.170(0.029) * *$ & $-0.045(0.019) *$ & $-0.027(0.008)^{* *}$ & $-0.003(0.041)^{*}$ \\
\hline$? \log \mathrm{UC}_{\mathrm{i}, \mathrm{t}-2}$ & $-0.072(0.021)^{* *}$ & $-0.002(0.011)$ & $-0.011(0.005)^{*}$ & $0.032(0.035)$ \\
\hline$? \log \mathrm{UC}_{\mathrm{i}, \mathrm{t}-3}$ & $-0.029(0.015)$ & $0.007(0.007)$ & $-0.004(0.004)$ & $0.017(0.028)$ \\
\hline$\sum ? \log \mathrm{UC}_{\mathrm{i}, \mathrm{t}-\mathrm{n}}$ & $-0.557(0.134) * *$ & $-0.095(0.037)^{*}$ & $-0.087(0.030)^{* * *}$ & $-0.228(0.177)$ \\
\hline $\begin{array}{l}\text { Long-term user } \\
\text { cost elasticity }\end{array}$ & $-0.663(0.167)^{* * *}$ & $-0.106(0.048)^{*}$ & $-0.111(0.039)^{* *}$ & $-0.259(0.201)$ \\
\hline No. of obs. & 16,858 & 33,453 & 62,447 & 8,855 \\
\hline No. of firms & 5,876 & 6,946 & 8,019 & 2,034 \\
\hline Sargan-Hansen test & $69.81(\mathrm{p}=0.29)$ & $105.12(\mathrm{p}=0.09)$ & $126.80(\mathrm{p}=0.09)$ & $127.26(\mathrm{p}=0.09)$ \\
\hline $\mathrm{AR}(1)$ & $13.74 * *$ & $-6.51 * *$ & $-30.90 * *$ & $-14.37 * *$ \\
\hline $\mathrm{AR}(2)$ & $-2.03(\mathrm{p}=0.04)^{*}$ & $-2.17(\mathrm{p}=0.03)^{*}$ & $0.08(\mathrm{p}=0.99)$ & $-0.19(\mathrm{p}=0.85)$ \\
\hline
\end{tabular}

Estimation method: 2-step GMM estimates, including time dummies

* Significant at the 5\% level. ** Significant at the $1 \%$ level.

Instruments: Germany: lags 2 and earlier of $\mathrm{I} / \mathrm{K}, ? \operatorname{logS}$ and ? $\log \mathrm{UC}$; France: $\mathrm{I} / \mathrm{K} \operatorname{lags} 3$ to 5 ; ? $\operatorname{logS} \operatorname{lags} 2$ to 4 and ? $\log \mathrm{UC}$ lags 2 to 5 ; Italy: I/K lags 2 to 6 ; ? $\log \mathrm{S}$ and ? $\log \mathrm{UC}$ lags 2 to 4 .; Spain: lags 2 to 5 of I/K, ? $\log \mathrm{S}$ and ? $\log \mathrm{UC}$. 
For all countries, with the partial exception of Spain, the long-run sales elasticities are similar to the WITHIN results. The point estimates increase somewhat for Germany, France and Italy, and decrease for Spain, but the effect of sales on capital remains statistically significant. The effect of sales on investment is clearly a robust feature in every country.

What is striking, however, is how the point estimates of the long-run user cost elasticities change when moving to GMM. These differences are non-uniform across countries. The GMM results show a slightly higher point estimate of the long-run user cost elasticity for Germany (-0.663), a dramatically lower one for France (-0.106) and Italy (-0.111) and a dramatically higher one for Spain (-.259).

So far these are the results obtained by means of a common specification. Before proceeding it is worth mentioning some robustness checks made for each country. Comparison with other results is obtained either by running regressions with a slightly modified set of instruments (results not shown) or by taking stock of the results presented in the companion papers of the Monetary Transmission project.

For Germany, the $\operatorname{AR}(2)$ statistics in the specification presented in Table 3 show that there might be an autocorrelation problem in the residuals. It is interesting to note that, using King-Fullerton user costs, von Kalckreuth (2001) obtains a smaller user cost elasticity of 0.522 for the same model. For France, the significance level of the elasticity of I/K to the user cost turns out to be dependent on the choice of instruments. For Italy, a sensitivity analysis of the results obtained with this specification was conducted by trying different instrument sets. By using a more parsimonious set of instruments, excluding lags 2 and 3 of the user cost, the long-run effect of the user cost is -.234 , more similar to the outcome of the WITHIN regression. Moreover, the Sargan test accepts the set of instruments at a higher confidence level. The effect of sales is similar to the one observed in Table 3. For Spain, the use of a more parsimonious specification leads again to more precise estimates. When removing insignificant lags, the point estimates of the remaining regressors do not significantly vary and the standard errors for the long-run elasticities are significantly lower. In particular, the point estimate for the long-run sales elasticity is 0.098 with a standard error of 0.039 , and the point estimate of the long-run user cost elasticity is 0.273 with a standard error of 0.131 .

It is important to investigate whether the sales and user cost elasticities are sensitive to adding cash flow to the regression. Since Fazzari, Hubbard and Petersen (1988) it is usual to enter cash flow in the regression to allow for liquidity constraints. The results estimated by GMM are presented in Table 4. 
Table 4 : ADL Models of Investment Demand - 3 lags including cash flow GMM estimates, Dependent Variable: $\mathbf{I}_{\mathrm{i}, \mathrm{t} / \mathrm{K}} \mathbf{K}_{\mathrm{I}, \mathrm{t}-1}$

\begin{tabular}{|c|c|c|c|c|}
\hline $\begin{array}{l}\text { Explanatory } \\
\text { Variable }\end{array}$ & GERMANY & FRANCE & ITALY & SPAIN \\
\hline $\mathrm{I}_{\mathrm{i}, \mathrm{t}-1} / \mathrm{K}_{\mathrm{i}, \mathrm{t}-2}$ & $0.124(0.017)^{* *}$ & $0.086(0.010)^{* *}$ & $0.168(0.011)^{* *}$ & $0.120(0.021)^{* *}$ \\
\hline $\mathrm{I}_{\mathrm{i}, \mathrm{t}-2} / \mathrm{K}_{\mathrm{i}, \mathrm{t}-3}$ & $0.002(0.009)$ & $0.016(0.007)^{*}$ & $0.024(0.006)^{* *}$ & $0.007(0.014)$ \\
\hline $\mathrm{I}_{\mathrm{i}, \mathrm{t}-\mathrm{3}} / \mathrm{K}_{\mathrm{i}, \mathrm{t}-\mathrm{4}}$ & $0.005(0.007)$ & $0.014(0.006)^{*}$ & $0.018(0.005)^{* *}$ & $0.010(0.012)$ \\
\hline$\sum \mathrm{I}_{\mathrm{i}, \mathrm{t}-\mathrm{n}} / \mathrm{K}_{\mathrm{i}, \mathrm{t}-\mathrm{n}-\mathrm{l}}$ & $0.131(0.026) * *$ & $0.116(0.033) * *$ & $0.206(0.016) * *$ & $0.137(0.038) * *$ \\
\hline$? \log S_{\mathrm{i}, \mathrm{t}}$ & $0.142(0.054)^{* *}$ & $0.031(0.040)$ & $0.045(0.033)$ & $-0.043(0.063)$ \\
\hline$? \log S_{\mathrm{i}, \mathrm{t}-1}$ & $0.097(0.014)^{* *}$ & $0.055(0.009)^{* *}$ & $0.039(0.006)^{* *}$ & $0.028(0.018)$ \\
\hline$? \log S_{\mathrm{i}, \mathrm{t}-2}$ & $0.061(0.011)^{* *}$ & $0.017(0.007)^{*}$ & $0.018(0.005)^{* *}$ & $0.014(0.014)$ \\
\hline$? \log \mathrm{S}_{\mathrm{i}, \mathrm{t}-3}$ & $0.036(0.010)^{* *}$ & $0.007(0.005)$ & $0.007(0.004)$ & $0.016(0.013)$ \\
\hline$\Sigma ? \log \mathrm{S}_{\mathrm{i}, \mathrm{t}-\mathrm{n}}$ & $0.338(0.068)^{* *}$ & $0.110(0.039) * *$ & $0.109(0.040)^{* *}$ & $0.015(0.075)$ \\
\hline $\begin{array}{l}\text { Long-term sales } \\
\text { elasticity }\end{array}$ & $0.387(0.077) * *$ & $0.124(0.046)^{* *}$ & $0.138(0.050)^{* *}$ & $0.018(0.087)$ \\
\hline$? \log \mathrm{UC}_{\mathrm{i}, \mathrm{t}}$ & $-0.220(0.080)^{* *}$ & $0.002(0.030)$ & $-0.079(0.021) * *$ & $-0.279(0.126)^{* *}$ \\
\hline$? \log \mathrm{UC}_{\mathrm{i}, \mathrm{t}-1}$ & $-0.151(0.028)^{* *}$ & $-0.030(0.03)$ & $-0.055(0.017) * *$ & $-0.018(0.040)$ \\
\hline$? \log \mathrm{UC}_{\mathrm{i}, \mathrm{t}-2}$ & $-0.060(0.020) * *$ & $0.002(0.013)$ & $-0.021(0.013)$ & $0.036(0.034)$ \\
\hline$? \log \mathrm{UC}_{\mathrm{i}, \mathrm{t}-3}$ & $-0.021(0.015)$ & $0.002(0.007)$ & $-0.006(0.005)$ & $0.021(0.027)$ \\
\hline$\Sigma ? \log \mathrm{UC}_{\mathrm{i}, \mathrm{t}-\mathrm{n}}$ & $-0.452(0.124) * *$ & $-0.024(0.032)$ & $-0.161(0.048)^{* *}$ & $-0.240(0.171)$ \\
\hline $\begin{array}{l}\text { Long-term user } \\
\text { cost elasticity }\end{array}$ & $-0.521(0.148)^{* *}$ & $-0.027(0.039)$ & $-0.204(0.060)^{* *}$ & $-0.278(0.198)$ \\
\hline $\mathrm{CF}_{\mathrm{i}, \mathrm{t}} / \mathrm{K}_{\mathrm{i}, \mathrm{t}-1}$ & $0.043(0.036)$ & $0.056(0.030)^{*}$ & $0.255(0.035)^{* *}$ & $0.121(0.032)^{* *}$ \\
\hline $\mathrm{CF}_{\mathrm{i}, \mathrm{t}-1} / \mathrm{K}_{\mathrm{i}, \mathrm{t}-2}$ & $0.011(0.012)$ & $0.091(0.015)^{* *}$ & $-0.025(0.019)$ & $0.037(0.022)^{*}$ \\
\hline $\mathrm{CF}_{\mathrm{i}, \mathrm{t}-2} / \mathrm{K}_{\mathrm{i}, \mathrm{t}-3}$ & $0.011(0.006)$ & $0.018(0.007)^{* *}$ & $0.008(0.007)$ & $-0.019(0.009) * *$ \\
\hline $\mathrm{CF}_{\mathrm{i}, \mathrm{t}-3} / \mathrm{K}_{\mathrm{i}, \mathrm{t}-4}$ & $0.004(0.005)$ & $0.008(0.005)$ & $0.000(0.006)$ & $-0.006(0.008)$ \\
\hline$\Sigma \mathrm{CF}_{\mathrm{I}, \mathrm{t}-\mathrm{n}} / \mathrm{K}_{\mathrm{i}, \mathrm{t}-\mathrm{n}-1}$ & $0.069(0.027)^{*}$ & $0.173(0.030)^{* *}$ & $0.238(0.022) * *$ & $0.133(0.032) * *$ \\
\hline $\begin{array}{l}\text { Long-term cash } \\
\text { flow sensitivity }\end{array}$ & $0.079(0.031)^{*}$ & $0.196(0.039) * *$ & $0.301(0.028)^{* *}$ & $0.153(0.037)^{* *}$ \\
\hline No. of obs. & 16,858 & 33,453 & 62,447 & 8,855 \\
\hline No. of firms & 5,876 & 6,946 & 8,019 & 2,034 \\
\hline Sargan-Hansen test & $91.80(\mathrm{p}=0.29)$ & $133.40(\mathrm{p}=0.43)$ & $127.20(\mathrm{p}=0.40)$ & $149.81(\mathrm{p}=0.17)$ \\
\hline $\mathrm{AR}(1)$ & $13.72 * *$ & $-24.60 * *$ & $-30.10 * *$ & $-14.62 * *$ \\
\hline $\mathrm{AR}(2)$ & $2.08(\mathrm{p}=0.04)^{*}$ & $1.21(\mathrm{p}=0.23)$ & $-0.18(\mathrm{p}=0.86)$ & $0.13(\mathrm{p}=0.90)$ \\
\hline
\end{tabular}

Estimation method: 2-step GMM estimates, including time dummies

* Significant at the $5 \%$ level. ** Significant at the $1 \%$ level.

Instruments: Germany: lags 2 and earlier of all explanatory variables; France: lags 2 to 5 of $\mathrm{I} / \mathrm{K}$, $\mathrm{CF} / \mathrm{K}$ and $\Delta \log \mathrm{S}$, and lags 3 to 5 of $\Delta \log \mathrm{UC}$; Spain: lags 2 to 5 of $\mathrm{I} / \mathrm{K}, \mathrm{CF} / \mathrm{K}$ and $\Delta \log \mathrm{UC}$, and lags 2 to 4 of $\Delta \log S$; Italy: I/K lags 2 to 6 ; ? $\operatorname{logS}$ lags 2 to $4 ;$ ? $\operatorname{logUC}$ lag $4 ; \mathrm{CF} / \mathrm{K}$ lags 2 to 5.

As is generally the case in the empirical literature, the cash flow capital ratio enters significantly and with a positive sign. The total effect of cash flow on $\mathrm{I} / \mathrm{K}$ ranges from a low of 0.079 in Germany to a high of 0.301 in Italy. The higher coefficient with respect to those obtained in the other countries could indicate that firms' balance-sheet conditions are relatively important in Italy. ${ }^{16}$ Also, the sales elasticity goes down substantively for all

\footnotetext{
16 On the other hand, as is well discussed by Bond et al. (1997), a positive effect of cash flow on investment does not necessarily reflect the presence of financial constraints. If higher cash flows are a good predictor of high activity in the future, it may very well be that a positive relationship between investment and cash flow does not reflect the existence of financial constraints. To partially address this criticism, the regression for Italy was re-run using liquidity stock as a measure of
} 
countries. Since cash flow might be a proxy for future profitability and future sales, this result was to be expected. Likewise, in the former regression, the sales variable might have picked up some effects that should really have been attributed to liquidity and profits. The long-run user cost elasticities are different with respect to the former GMM results. They are lower for Germany and Italy if for those countries we compare the results obtained using the same set of instruments, and they are close to zero for France.

The change in the long-run user cost elasticity when cash flow is entered into the regression can be explained by how the user cost was constructed. The apparent interest-rate variable used for constructing the user cost of capital is interest payments divided by the amount of debt. This induces a correlation with cash flow, of which interest payments also are an important part. As noted by Chirinko, Fazzari and Meyer (1999) "in the regression without cash flow the estimated sum of coefficients of the user cost captures both the conventional substitution effect as well as the income effect induced by financing constraints, which affect investment in the same direction".

Overall, the results in Tables 2, 3 and 4 suggest that sales, user cost and cash flow are all important determinants of investment. That user cost enters significantly in investment regressions is an important result, since it is the prerequisite for an interest-rate channel. The finding that (for most countries) the user cost elasticity varies substantially according to estimation method and specification is less satisfying. (Note that this is also the case for the U.S. in Chirinko, Fazzari and Meyer (1999).) However, given that the user cost is a rather elusive variable, this is not too surprising.

\section{The broad credit channel in the euro area}

In this section we test whether small and large firms show different investment behaviour. We are especially interested in differences in the coefficient estimates of the cash flow capital ratio. By testing whether the long-run effect of the cash flow capital ratio is significantly different for small firms than for large firms, we are able to compare the behaviour of firms that are likely to be characterised by weaker balance sheets with that of other firms.

It is well known that "models that incorporate financial frictions are more relevant for certain types of agents, certain classes of borrowers, and certain sectors of the economy" (Gilchrist and Zakrajsek, 1995). Moreover, as these authors note: "because of the difficul-

firms' balance-sheet conditions. This variable should be less correlated with expectations of future demand conditions: results (not reported) indicate that liquidity, too, has a positive and significant effect on capital formation; in the regression the sign and significance of sales and the user cost remain unchanged. 
ties associated with formulating and estimating true structural models, empirical exercises seeking to establish the validity of either a credit channel or a financial accelerator must make comparisons against benchmarks where such credit effects are less likely to be relevant".

Sample comparisons using size as a discriminating characteristic of the balance-sheet conditions of firms are commonly used in the empirical literature that has examined the link between financial constraints and investment spending (see Schiantarelli, 1995 for a discussion). Smaller firms are more likely to be less collateralised, to be more opaque towards external investors and, insofar as age is correlated with small size, have less established contacts with lenders, thus making it more difficult to distinguish between good and bad firms. Other characteristics that have been commonly used in these tests are dividend payout behaviour, group membership, the nature of the bank-firm relationship, and the degree of ownership concentration. In particular circumstances and in some countries, these characteristics may very well be more important than size. In fact, as Schiantarelli (1995) notes, one problem with splitting the sample along one firm characteristic is that "[this] single indicator may or may not be a sufficient statistic for the existence of liquidity constraints".

Analysis of the institutional characteristics that in each country can blur the relevance of the size split is beyond the scope of this paper. In the companion papers that focus on single country evidence, other firm characteristics that might prove relevant for the transmission of monetary policy shocks via the balance sheet are analysed. (See, for example, Chatelain and Tiomo (2001) for France, von Kalckreuth (2001) for Germany, Valderrama (2001) for Austria, Butzen, Fuss and Vermeulen (2001) for Belgium and Gaiotti and Generale (2001) for Italy). We present here only the size split results since these are probably more easily comparable across countries.

Table 5 : Long-term elasticity of sales and user cost and long-term effect of cash flow on large and small firms. GMM ADL3 with CF

\begin{tabular}{|c|c|c|c|c|}
\hline & GERMANY & FRANCE & ITALY & SPAIN \\
\hline ? $\log \mathrm{S}$ large firms & $0.337(0.086) * *$ & $0.073(0.032)^{*}$ & $0.108(0.051)^{*}$ & $0.040(0.012)^{* *}$ \\
\hline Diff. Small - Large & $-0.029(0.125)$ & $0.042(0.040)$ & $0.027(0.079) *$ & $-0.031(0.021)$ \\
\hline$? \log \mathrm{UC}_{\mathrm{i}, \text { large firms }}$ & $-0.512(0.173) * *$ & $-0.053(0.040)$ & $-0.238(0.060) * *$ & $-0.153(0.082)^{*}$ \\
\hline Diff. Small - Large & $0.063(0.255)$ & $0.057(0.180)$ & \begin{tabular}{|l|}
$0.024(0.098)$ \\
\end{tabular} & $0.072(0.167)$ \\
\hline $\mathrm{CF} / \mathrm{K}$ large firms & $0.092(0.038)^{*}$ & $0.221(0.030) * *$ & $0.196(0.027)^{* *}$ & $0.116(0.021)^{* *}$ \\
\hline Diff. Small - Large & $-0.050(0.050)$ & $-0.035(0.031)$ & $0.144(0.045) * *$ & $0.030(0.033)$ \\
\hline
\end{tabular}

$*$ Significant at the $5 \%$ level. $* *$ Significant at the $1 \%$ level.

Table 5 contains the regression results of equation (9) when allowing for different coefficients for user cost growth, sales growth and the cash flow capital ratio for large and small firms. With the exception of Italy, we find no systematic differences between large and 
small firms across countries. This is the case for both the sales and user cost elasticities and for the effect of cash flow. The point estimates of the differences in elasticities are non-systematically positive or negative and usually non-significant.

For Italy, the sum of the cash flow coefficients for small firms is significantly higher than for large firms. The fact that balance-sheet conditions are more important for firms that are probably more exposed to problems of information asymmetries seems to confirm the existence of a broad credit channel in Italy. These results seem robust to different model specifications, such as the error-correction model estimated in Gaiotti and Generale (2001).

We think however that it would be too early to conclude that the broad credit channel is only operative in Italy. Clearly, more sophisticated sample splits might provide significant differences across firms belonging to different groups. The results in Table 5 do indicate that identifying the broad credit channel by only taking into account the size classification might be an oversimplification in most euro-area countries. Size might not be a sufficient or even correct indicator for some countries of informational asymmetries that are the basis for broad credit channel effects.

Indeed, as already noted above, the companion papers to this research project address the issue of heterogeneity across firms under many other different dimensions. For Germany, when firms' ratings are used as a proxy of financial constraints, it turns out that those with a lower rating are more sensitive to financial variables (von Kalckreuth, 2001). For France, firms belonging to the equipment goods sector, firms with a lower rating and firms with a high share of trade credit in the balance sheet are also more sensitive to cash flow (Chatelain and Tiomo, 2001). In addition, for France, the introduction of dummy variables which isolate firms that are more sensitive to cash flow has the effect of shifting back the user cost elasticity to its level obtained without cash flow, i.e. a significant value below 0.1 . For Italy, firms with a high share of intangible assets over total assets, an indication of the extent of asymmetric information, respond more to variables that approximate their financial condition (Gaiotti and Generale, 2001). Moreover, results for other countries that we do not analyse by means of a common specification point to the presence of heterogeneity. For Austria, the existence of a "Hausbank" (main bank) significantly affects the transmission of monetary impulses. Valderrama (2001) finds that firms having closer relationships with the main bank react less to cash flow and more to the user cost than firms with less "intense" relationships. In Luxembourg, younger firms seem more exposed to liquidity constraints, measured by means of various financial ratios (Lünnemann and Mathä, 2001). For Belgium, Butzen, Fuss and Vermeulen (2001) document a high degree 
of heterogeneity in firms' reaction to monetary policy depending on the sectors in which the firms operate.

\section{User cost, cash flow, sales and monetary policy: a simulation exercise ${ }^{17}$}

In this section, we first analyse the dynamics of the regression equation. We then perform a more complicated simulation exercise to determine the elasticity of investment with respect to user cost, sales and cash flow. We finally determine the elasticity of investment with respect to the market interest rate.

We use the point estimates of the coefficients as presented in Table 4. In the following, we present the short run time profile of $\mathrm{I} / \mathrm{K}$ in the presence of simple shocks to the explanatory variables and compare these profiles over the four European countries.

Consider the following experiment. Imagine a firm for which user cost growth, sales growth, $\mathrm{CF} / \mathrm{K}$ and $\mathrm{I} / \mathrm{K}$ are all at their steady state path. Next, imagine one single shock at time $t$ to user cost growth, e.g. user cost growth at time $t$ is equal to its steady state path value plus 0.01 , and that after time $t$ user cost growth is again at its steady state path. What happens to $\mathrm{I} / \mathrm{K}$ at time $\mathrm{t}, \mathrm{t}+1$, etc., assuming the paths of the other variables i.e. real sales growth and $C F / K$ are held constant at their steady state path? A similar experiment can be performed for real sales growth (again holding the other variables at their steady state), or for $\mathrm{CF} / \mathrm{K}$.

Note that one could object to this type of analysis on multiple grounds. First, user cost growth, sales growth and $\mathrm{CF} / \mathrm{K}$ are all endogenous, implying that shocks to one variable might have immediate or lagged effects on the other variables. Basically, the regression equation is just one equation describing $\mathrm{I} / \mathrm{K}$. In reality, the behaviour of all relevant variables should be described with a multi-equation system. This, however, is outside the scope of this paper. Second, the regression equation contains the capital stock at both the left-hand side and right-hand side (I/K and $\mathrm{CF} / \mathrm{K})$. Since movements in $\mathrm{I} / \mathrm{K}$ will ultimately move $\mathrm{K}, \mathrm{CF} / \mathrm{K}$ will also change (unless $\mathrm{CF}$ moves by the same amount as $\mathrm{K}$ ). In this first exercise, we also abstract from this second objection (hence implicitly letting CF move at the same rate of $\mathrm{K}$ when holding $\mathrm{CF} / \mathrm{K}$ constant.).

Given the above two objections, we still believe the experiment to be of value. First, it provides a description of the dynamics of the equation concentrating on one variable at a time. Second, more complicated experiments in which shocks to certain variables coincide with (lagged) shocks to other variables are just linear combinations of the above simple

${ }^{17}$ We want to thank Daniele Terlizzese for a patient and productive discussion of the issues involved. 
experiments. For instance, if one considers a simultaneous shock to sales growth and $\mathrm{CF} / \mathrm{K}$, then one can simply add the effects on $\mathrm{I} / \mathrm{K}$.

We consider two types of shocks for this experiment. We first consider a shock of $1 \%$ (i.e. the explanatory variable at time $t$ has the value of its steady state plus 0.01 ). It is necessary to see that such a transitory shock to the growth rates of user costs or sales corresponds to a permanent shock to the level of this variable. We next consider a shock which has a magnitude of one standard deviation of the within-firm variation of the variable. We find this last shock especially appealing because it represents a shock relative to the 'normal' variation present in the variable in our data. We indeed find that the within-firm variation of user cost growth, sales growth and $\mathrm{CF} / \mathrm{K}$ is much larger than $1 \%$ and differs substantially across variables and across countries.

Tables 6.1-6.3 present the deviation of $\mathrm{I} / \mathrm{K}$ from its steady state path after those two types of shocks, adopting as a benchmark the specification presented in Table 4. Table 6.1 shows the change in $\mathrm{I} / \mathrm{K}$ after a $1 \%$ (column 1 ) or one standard deviation shock (column 2) in user cost growth. Most of the effects take place within the first two years. A $1 \%$ increase in user cost growth has the largest effect in Spain and Germany. Misleadingly, the magnitude of the effect seems small. However, in the data, a one standard deviation change in the user cost growth rate is much larger than 1\%; it is $10.6 \%$ in Germany, $13.7 \%$ in France, $26.1 \%$ in Italy and $14.5 \%$ in Spain. In the first period, a rise in the user cost growth in Germany of one standard deviation depresses $\mathrm{I} / \mathrm{K}$ by 2.33 percentage points. Given the level of average gross investment per unit of capital of 0.181 in Germany, this translates into a drop to 0.1577 (i.e. 0.181-0.0233). Similar larger effects can be observed in Italy and Spain. The comparison between columns 1 and 2 reveal some interesting features of the data and the regression result. We can interpret the regression equation as a description of investment behaviour in the period of investigation. Then it is clear that two distinct features have determined this behaviour: the magnitude of the reaction of the $\mathrm{I} / \mathrm{K}$ ratio to shocks to the explanatory variables, and the magnitude of those shocks. For instance, whereas the contemporaneous reaction to identical user cost growth shocks in Italy was much smaller than in Germany (as evidenced in column 1), Italian user cost growth shocks were on average much larger than German shocks. Combining those two features implies similar behaviour of the $\mathrm{I} / \mathrm{K}$ ratio after a one standard deviation shock (as evidenced in column 2). Note that our regressions are conditional on the historical variation in the data. This historical variation from the time before EMU could be quite different from future variation. 
Table 6.1. Change in I/K after a one-time $1 \%$ or one standard deviation increase in the user cost growth at time $t$

\begin{tabular}{|l|c|c|c|c|c|c|c|c|}
\hline & \multicolumn{2}{|c|}{ Germany } & \multicolumn{2}{c|}{ France } & \multicolumn{3}{c|}{ Italy } & \multicolumn{2}{c|}{ Spain } \\
\hline & $(1)$ & $(2)$ & $(1)$ & $(2)$ & $(1)$ & $(2)$ & $(1)$ & $(2)$ \\
\hline & & & & & & & & \\
\hline $\mathrm{T}$ & -0.22 & -2.33 & 0.00 & 0.03 & -0.08 & -2.06 & -0.28 & -4.05 \\
\hline $\mathrm{t}+1$ & -0.18 & -1.88 & -0.03 & -0.41 & -0.07 & -1.78 & -0.05 & -0.75 \\
\hline $\mathrm{t}+2$ & -0.08 & -0.84 & 0.00 & -0.01 & -0.03 & -0.90 & 0.03 & 0.40 \\
\hline $\mathrm{t}+3$ & -0.04 & -0.38 & 0.00 & 0.02 & -0.01 & -0.39 & 0.02 & 0.31 \\
\hline \multicolumn{7}{|l|}{} \\
\hline
\end{tabular}

Table 6.2 shows the change in $\mathrm{I} / \mathrm{K}$ after both a $1 \%$ (column 1 ) or one standard deviation shock (column 2) in sales growth. Again, the largest effects can be observed in the first two years. The sales effect is largest in Germany. A one standard deviation increase in the growth rate of sales increases the $\mathrm{I} / \mathrm{K}$ ratio by $2.26 \%$ in the same year.

Table 6.3 shows the change in $\mathrm{I} / \mathrm{K}$ after a $1 \%$ (column 1 ) or one standard deviation shock (column 2) in the $\mathrm{CF} / \mathrm{K}$ ratio. The contemporaneous effects are quite large. They are the smallest in Germany. Investment in Italian and Spanish firms, in particular, seems to move quite strongly simultaneously with $\mathrm{CF} / \mathrm{K}$ movements.

Table 6.2. Change in $\mathbf{I} / \mathrm{K}$ after a one-time $1 \%$ or one standard deviation increase in sales growth at time $t$

\begin{tabular}{|l|c|c|c|c|c|c|c|c|}
\hline & \multicolumn{2}{|c|}{ Germany } & \multicolumn{2}{c|}{ France } & \multicolumn{2}{c|}{ Italy } & \multicolumn{2}{c|}{ Spain } \\
\hline & $(1)$ & $(2)$ & $(1)$ & $(2)$ & $(1)$ & $(2)$ & $(1)$ & $(2)$ \\
\hline & & & & & & & & \\
\hline $\mathrm{T}$ & 0.16 & 2.26 & 0.03 & 0.44 & 0.05 & 0.84 & -0.04 & -0.68 \\
\hline $\mathrm{t}+1$ & 0.12 & 1.77 & 0.06 & 0.81 & 0.05 & 0.87 & 0.02 & 0.36 \\
\hline $\mathrm{t}+2$ & 0.08 & 1.16 & 0.02 & 0.32 & 0.03 & 0.50 & 0.02 & 0.26 \\
\hline $\mathrm{t}+3$ & 0.04 & 0.59 & 0.01 & 0.15 & 0.01 & 0.25 & 0.02 & 0.28 \\
\hline & & & & & & & & \\
\hline
\end{tabular}

A 1 standard deviation increase in sales growth is equal 0.145 in Germany, 0.141 in France, 0.187 in Italy and 0.159 in Spain.

Figures in columns (1) and (2), respectively, represent the deviation of I/K in percentage points after a $1 \%$ and one standard deviation increase in sales growth.

The regression equation 'explains' $\mathrm{I} / \mathrm{K}$ in terms of user cost growth, sales growth and the $\mathrm{CF} / \mathrm{K}$ ratio. However, the reader might find it more natural to think of the level of investment in terms of the level of user cost, sales or cash flow. After some algebra, the regression equation can also be used to calculate the elasticity of investment (I) with respect to the user cost, sales or cash flow. For example, by the elasticity of investment with respect to the user cost, we mean the percentage change of investment (i.e. I, not $\mathrm{I} / \mathrm{K}$ ) due to a 'permanent' $1 \%$ change (from the base path) in the user cost level. The wording 'perma- 
nent' is important here. As in the first set of simulations given by Tables 6.1-6.3, a permanent change in the user cost level (from the base path) is given by a one-time 1\% change in the growth rate (from the base path) of user costs. Appendix $\mathrm{C}$ provides details about the calculation.

Table 6.3. Change in $\mathrm{I} / \mathrm{K}$ after a one-time $1 \%$ or one standard deviation increase in $\mathrm{CF} / \mathrm{K}$ at time $\mathbf{t}$

\begin{tabular}{|l|c|c|c|c|c|c|c|c|}
\hline & \multicolumn{2}{|c|}{ Germany } & \multicolumn{2}{c|}{ France } & \multicolumn{2}{c|}{ Italy } & \multicolumn{2}{c|}{ Spain } \\
\hline & $(1)$ & $(2)$ & $(1)$ & $(2)$ & $(1)$ & $(2)$ & $(1)$ & $(2)$ \\
\hline & & & & & & & & \\
\hline $\mathrm{T}$ & 0.04 & 1.28 & 0.06 & 1.29 & 0.26 & 3.90 & 0.12 & 3.74 \\
\hline $\mathrm{t}+1$ & 0.02 & 0.47 & 0.10 & 2.21 & 0.02 & 0.27 & 0.05 & 1.59 \\
\hline $\mathrm{t}+2$ & 0.01 & 0.40 & 0.03 & 0.63 & 0.02 & 0.26 & -0.01 & -0.37 \\
\hline $\mathrm{t}+3$ & 0.01 & 0.17 & 0.01 & 0.29 & 0.01 & 0.12 & -0.01 & -0.18 \\
\hline & & & & & & & & \\
\hline
\end{tabular}

A 1 standard deviation increase in the cash flow capital ratio is equal to 0.305 in Germany, 0.231 in France, 0.153 in Italy and 0.309 in Spain.

Figures in columns (1) and (2), respectively, represent the deviation of I/K in percentage points after a $1 \%$ and one standard deviation increase in the cash flow capital ratio.

Tables 7.1-7.3 provide the elasticity of investment with respect to (the levels of) user cost, sales and cash flow. A substantive elasticity of investment with respect to its user cost is a necessary condition for an interest channel to be operative. As evidenced in Table 7.1, the elasticity of contemporaneous investment with respect to the user cost is quite large in Germany (-1.21), Italy (-0.63) and Spain (-1.49). It is negligible in France (0.02), but becomes non-negligible in the year after $(-0.24)$. The elasticity at time $t+1$ remains substantive in Germany, Italy and Spain, but is smaller. Overall, Table 7.1 provides evidence of a strong and rapid reaction of investment to user cost changes.

Table 7.1. Elasticity of investment with respect to the user cost

\begin{tabular}{|l|c|c|c|c|}
\hline & Germany & France & Italy & Spain \\
\hline & & & & \\
\hline $\mathrm{T}$ & -1.21 & 0.02 & -0.63 & -1.49 \\
\hline $\mathrm{T}+1$ & -1.17 & -0.24 & -0.59 & -0.48 \\
\hline $\mathrm{T}+2$ & -0.79 & -0.03 & -0.36 & -0.05 \\
\hline $\mathrm{T}+3$ & -0.61 & 0.00 & -0.21 & -0.06 \\
\hline
\end{tabular}

Table 7.2 presents the elasticity of investment with respect to sales. The contemporaneous elasticities are 0.86 for Germany, 0.25 for France, 0.36 for Italy and -0.23 for Spain. Surprisingly in Germany, Italy and Spain, investment seems to have a lower contemporaneous elasticity with respect to sales than with respect to its user cost. Given the emphasis on the sales accelerator model and the general ignoring of user cost in the investment literature, this is a provocative result. Although sales growth does undeniably have a positive effect on investment, one should not ignore user costs. 
Table 7.2. Elasticity of investment with respect to sales

\begin{tabular}{|l|c|c|c|c|}
\hline & Germany & France & Italy & Spain \\
\hline & & & & -0.23 \\
\hline $\mathrm{T}$ & 0.86 & 0.25 & 0.36 & 0.09 \\
\hline $\mathrm{T}+1$ & 0.82 & 0.50 & 0.40 & 0.08 \\
\hline $\mathrm{T}+2$ & 0.69 & 0.25 & 0.27 & 0.10 \\
\hline $\mathrm{T}+3$ & 0.54 & 0.15 & 0.17 & \\
\hline
\end{tabular}

Table 7.3 provides the elasticity of investment with respect to cash flow. Due to the past $\mathrm{CF} / \mathrm{K}$ ratios in the regression, the effect of a permanent increase in cash flow gradually evolves and accumulates over time. The picture that emerges is mixed. In Germany and France the elasticity is generally lower than the sales elasticity. In Italy and Spain it is generally higher.

Table 7.3. Elasticity of investment with respect to $\mathrm{CF}$

\begin{tabular}{|l|c|c|c|c|}
\hline & Germany & France & Italy & Spain \\
\hline & & & & \\
\hline $\mathrm{T}$ & 0.06 & 0.15 & 0.40 & 0.24 \\
\hline $\mathrm{T}+1$ & 0.10 & 0.42 & 0.46 & 0.38 \\
\hline $\mathrm{T}+2$ & 0.13 & 0.54 & 0.52 & 0.39 \\
\hline $\mathrm{T}+3$ & 0.16 & 0.60 & 0.55 & 0.42 \\
\hline
\end{tabular}

To understand the effect of monetary policy on investment Tables 7.1-7.3 are not sufficient. A relevant question is: 'How do market interest rates affect user costs and cash flow in those four euro-area countries'? ${ }^{18}$ Essentially, the interest channel or 'cash flow channel' works through two stages. In the first stage, the market interest rate has to change firm fundamentals (user cost, and cash flow). In the second stage, these firm fundamentals have an effect on investment with the elasticities as presented in Tables 7.1-7.3. Below we present some evidence on the first stage and show how, combined with the second stage, the channels of monetary policy differ across countries.

We first investigate the effect of market interest rate changes on the user cost. The first important fact that should be noted is that interest rates form a part of the user cost of capital. The importance or weight of this part depends on the importance of the other parts such as depreciation and relative price changes. Since the user cost directly contains an interest rate in its definition, the elasticity of the user cost with respect to the interest rate can therefore be calculated directly. It is equal to:

\footnotetext{
${ }^{18}$ Another relevant question is: 'How do market interest rates affect sales?' We do not attempt to answer that question. Interest-rate shocks do not have a 'mechanical' effect on sales in the same way as interest-rate shocks have on user cost and cash flow (interest rates are part of user costs, and interest payments are part of cash flow). Although interest rates can influence firm-specific demand (e.g., for investment goods or durable consumer goods producing firms), this demand effect is much more difficult to quantify. Trying to do this here would require a whole new paper.
} 


$$
\frac{\partial U C_{i t}}{\partial i} * \frac{i}{U C_{i t}}=\frac{A I_{i t}\left(\frac{D_{i t}}{D_{i t}+E_{i t}}\right)\left(1-\tau_{t}\right)+\left(L D_{i t}\right)\left(\frac{E_{i t}}{D_{i t}+E_{i t}}\right)}{A I_{i t}\left(\frac{D_{i t}}{D_{i t}+E_{i t}}\right)\left(1-\tau_{t}\right)+\left(L D_{i t}\right)\left(\frac{E_{i t}}{D_{i t}+E_{i t}}\right)-\left(1-\delta_{s}\right) \frac{\Delta P_{s t+1}^{I}}{P^{I}}+\delta_{s t}}
$$

The elasticity is simply the weight of the interest rate in the user cost definition. Hence, if depreciation or changes in relative prices are large, interest changes will have a small effect on the user cost. Table 8 shows the relative importance of the interest rate in the user cost definition in the different countries for an average firm in the data set. It is relatively high in Spain and Italy, somewhat lower in France and lowest in Germany. Therefore, market interest rate changes will have larger effects on user cost in Italy and Spain than in France and Germany.

Table 8 : Important elasticities

\begin{tabular}{|l|l|l|l|l|}
\hline & Germany & France & Italy & Spain \\
\hline (1) $\frac{\partial u c}{\partial i} * \frac{i}{u c}$ & 0.32 & 0.58 & 0.70 & 0.65 \\
\hline (2) $\frac{\partial C F}{\partial i} * \frac{i}{C F}$ & -0.32 & -0.28 & -0.60 & -0.47 \\
\hline
\end{tabular}

We now consider the effect of a permanent $1 \%$ change in the market interest rate through the user cost. Note that by this we mean, for example, a change in the interest rate from $5 \%$ to $5.05 \%$, not from $5 \%$ to $6 \%$. Table 8 shows us how much the user cost will change permanently. So, for instance, a $1 \%$ permanent increase in the market interest rate leads to a user cost change of $0.32 \%$ in Germany and $0.70 \%$ in Italy. Combining this with the results of Table 7.1 gives us the dynamic effects on investment of a $1 \%$ change in the market interest rate. The results are presented in Table 9.

We find relatively large effects in Germany, Italy and Spain. If one were to consider, e.g., a 50 basis points increase in a market interest rate from $5 \%$ to $5.50 \%$, one would have to multiply the numbers in Table 9 by 10 . Such a policy experiment would lead to contemporaneous $3.9 \%$ decrease in investment in Germany, $4.5 \%$ in Italy, $9.8 \%$ in Spain and no effect in France.

Table 9. Elasticity of investment with respect to the market interest rate through the user cost

\begin{tabular}{|l|c|c|c|c|}
\hline & Germany & France & Italy & Spain \\
\hline & & & & -0.97 \\
\hline $\mathrm{T}$ & -0.39 & 0.01 & -0.44 & -0.31 \\
\hline $\mathrm{T}+1$ & -0.38 & -0.14 & -0.41 & -0.04 \\
\hline $\mathrm{T}+2$ & -0.25 & -0.02 & -0.25 & -0.04 \\
\hline $\mathrm{T}+3$ & -0.19 & 0.00 & -0.15 & \\
\hline
\end{tabular}


We also investigate the effect of a permanent change in the market interest rate on cash flow. Since interest payments are a flow, they decrease cash flow. When firms have higher interest payments to make, they have lower cash flow, ceteris paribus. The elasticity of cash flow with respect to the interest rate can also be calculated directly. It is equal to:

$$
\frac{\partial C F_{t}}{\partial i_{t-1}} * \frac{i_{t-1}}{C F_{t}}=-\frac{(1-\tau) i_{i, t-1} D_{i, t-1}}{(1-\tau)\left(p Y-\operatorname{Cos} t s-i_{i, t-1} D_{i, t-1}\right)},
$$

The elasticity is equal to the inverse coverage ratio, i.e. interest payments over cash flow. The higher the inverse coverage ratio is, the higher the effect of interest payments will be on cash flow. Table 8 shows the elasticity of cash flow with respect to the market interest rate for the average firm in the samples. Italy and Spain again display higher values for this elasticity. Presumably this is due to high nominal interest rates for both countries during the years of investigation.

Table 10 presents the effect on the growth rate of the capital stock (or investment) of a transitory increase of $1 \%$ of the interest rate through the effect on cash flow. The effects are in general relatively small in all countries. Consider again a $50 \mathrm{bp}$ increase in a market interest rate from $5 \%$ to $5.50 \%$. Such a policy experiment would lead, after the first year, to a contemporaneous $0.2 \%$ decrease in investment in Germany, $0.4 \%$ in France, $2.4 \%$ in Italy and $1.1 \%$ in Spain.

Table 10. Elasticity of investment with respect to the market interest rate through cash flow

\begin{tabular}{|l|c|c|c|c|}
\hline & Germany & France & Italy & Spain \\
\hline & & & & \\
\hline $\mathrm{T}$ & -0.02 & -0.04 & -0.24 & -0.11 \\
\hline $\mathrm{T}+1$ & -0.03 & -0.12 & -0.28 & -0.18 \\
\hline $\mathrm{T}+2$ & -0.04 & -0.15 & -0.31 & -0.18 \\
\hline $\mathrm{T}+3$ & -0.05 & -0.17 & -0.33 & -0.20 \\
\hline
\end{tabular}

\section{Conclusion}

This paper presents a comparable set of results on the monetary transmission channels on firm investment for the four largest countries of the euro area. We focus on two different channels that affect investment. The interest channel is operative when market interest fluctuations change the user cost of capital and hence investment. The broad credit channel is operative when market interest fluctuations change the balance-sheet condition and the available cash flow of firms and, through this, investment. This paper is the first to provide an investigation of those two channels for the four largest economies of the euro area, based on results from a unique comparative study using large firm databases for each 
country, containing a total of over 215,000 observations from 1985 to 1999. Its emphasis on using large micro-datasets makes this exercise an important complement to the vast macro-literature in which euro-area countries are compared.

We find investment to be sensitive to user cost changes in all those four countries. Most of the effect of user cost changes is born within the first two years. This implies an operative interest channel in these euro-area countries. We also find investment in all those countries to be quite sensitive to sales and cash flow movements. Furthermore, we have investigated whether significant differences exist between large and small firms in investment behaviour. We find that only in Italy do smaller firms react more to cash flow movements. We argue that size might not be the right indicator in all countries to investigate the broad credit channel. 


\section{APPENDIX}

\section{A: Cleaning of the samples:}

All the samples were cleaned for outliers by removing percentiles from the variables used in the regression. More details can be found in von Kalckreuth (2001), Gaiotti and Generale (2001), Chatelain and Tiomo (2001).

\section{B. Definition of the user cost variable}

The user cost is constructed as

$$
U C=\frac{P_{s t}{ }^{I}}{P_{s t}} \frac{\left(1-i t c_{t}-\tau_{t} z_{s}\right)}{\left(1-\tau_{t}\right)}\left[A I_{i t}\left(\frac{D_{i t}}{D_{i t}+E_{i t}}\right)\left(1-\tau_{t}\right)+\left(L D_{i}\right)\left(\frac{E_{i t}}{D_{i t}+E_{i t}}\right)-\left(1-\delta_{s}\right) \frac{\Delta P_{s t+1}{ }^{I}}{P^{I}{ }_{s t}}+\delta_{s}\right]
$$

where

i: firm-specific,

s: sector-specific,

t: time-varying,

$P^{I}$ the investment price, $P$ the value-added price,

$\tau$ the highest marginal corporate tax rate,

$\delta$ the depreciation rate.

AI: apparent interest rate, as interest payment over gross debt

D: gross debt

LD: long-term debt rate

E: book value of equity

z: present value of depreciation allowances

itc: investment tax credit.

\section{Simulation}

In this appendix we explain the calculation of the elasticity of investment with respect to user cost, sales and cash flow. It is largely based on an idea developed and explained to us by Daniele Terlizzese. Start from the estimated equation (where we have dropped the subscripts i):

$$
\begin{aligned}
& \frac{I_{t}}{K_{t-1}}=f+\omega_{1} \frac{I_{t-1}}{K_{t-2}}+\omega_{2} \frac{I_{t-2}}{K_{t-3}}+\omega_{3} \frac{I_{t-3}}{K_{t-4}}+\theta_{0} \Delta y_{t}+\theta_{1} \Delta y_{t-1}+\theta_{2} \Delta y_{t-2}+\theta_{3} \Delta y_{t-3}+ \\
& -\sigma_{0} \Delta u c_{t}-\sigma_{1} \Delta u c_{t-1}-\sigma_{2} \Delta u c_{t-2}-\sigma_{3} \Delta u c_{t-3}+\gamma_{1} \frac{C F_{t}}{K_{t-1}}+\gamma_{2} \frac{C F_{t-1}}{K_{t-2}}+\gamma_{3} \frac{C F_{t-2}}{K_{t-3}}+\gamma_{4} \frac{C F_{t-3}}{K_{t-4}}
\end{aligned}
$$

time dummies $+\varepsilon_{t}$ 
and the capital accumulation equation, $K_{t}=(1-\delta) K_{t-1}+I_{t}$

Let us define $g_{t} \equiv \frac{K_{t}-K_{t-1}}{K_{t-1}} \equiv \frac{I_{t}}{K_{t-1}}-\delta$. Then we can rewrite the estimated equation as:

$g_{t}=f+\delta\left(\omega_{1}+\omega_{2}+\omega_{3}-1\right)+\omega_{1} g_{t-1}+\omega_{2} g_{t-2}+\omega_{3} g_{t-3}+\theta_{0} \Delta y_{t}+\theta_{1} \Delta y_{t-1}+\theta_{2} \Delta y_{t-2}+\theta_{3} \Delta y_{t-3}+$

$-\sigma_{0} \Delta u c_{t}-\sigma_{1} \Delta u c_{t-1}-\sigma_{2} \Delta u c_{t-2}-\sigma_{3} \Delta u c_{t-3}+\gamma_{1} \frac{C F_{t}}{K_{t-1}}+\gamma_{2} \frac{C F_{t-1}}{K_{t-2}}+\gamma_{3} \frac{C F_{t-2}}{K_{t-3}}+\gamma_{4} \frac{C F_{t-3}}{K_{t-4}}$

time dummies $+\varepsilon_{t}$.

Let us now consider, starting in period t, a shock to $\Delta u c_{t}$ of $1 \%(0.01)$, define $g_{t}^{s}$ as the corresponding new value of $g_{t}$ and define $K_{t+\tau}^{s}$ as the corresponding new value of $K_{t+\tau}$.

Let us also define $\eta_{t+\tau} \equiv \frac{K_{t+\tau}^{s}-K_{t+\tau}}{K_{t+\tau}}$. Some algebra shows that:

$\eta_{t}=\frac{\left(g_{t}^{s}-g_{t}\right)}{\left(1+g_{t}\right)}$ and $\eta_{t+\tau}=\eta_{t+\tau-1} \frac{\left(1+g^{s}{ }_{t+\tau}\right)}{\left(1+g_{t+\tau}\right)}+\frac{\left(g_{t+\tau}^{s}-g_{t+\tau}\right)}{\left(1+g_{t+\tau}\right)}$

It is immediately clear that $g_{t}^{s}-g_{t}=-\sigma_{0} * 0.01$, and after some algebra we see that:

$$
\begin{aligned}
& g_{t+1}^{s}-g_{t+1}=\omega_{1}\left(g_{t}^{s}-g_{t}\right)-\sigma_{1} * 0.01-\gamma_{1} \frac{C F_{t+1}}{K_{t}} \frac{\eta_{t}}{1+\eta_{t}}, \\
& g_{t+2}^{s}-g_{t+2}=\omega_{1}\left(g_{t+1}^{s}-g_{t+1}\right)+\omega_{2}\left(g_{t}^{s}-g_{t}\right)-\sigma_{2} * 0.01-\gamma_{1} \frac{C F_{t+2}}{K_{t+1}} \frac{\eta_{t+1}}{1+\eta_{t+1}}-\gamma_{2} \frac{C F_{t+1}}{K_{t}} \frac{\eta_{t}}{1+\eta_{t}}, \\
& g_{t+3}^{s}-g_{t+3}=\omega_{1}\left(g_{t+2}^{s}-g_{t+2}\right)+\omega_{2}\left(g_{t+1}^{s}-g_{t+1}\right)+\omega_{3}\left(g_{t}^{s}-g_{t}\right)-\sigma_{3} * 0.01-\gamma_{1} \frac{C F_{t+3}}{K_{t+2}} \frac{\eta_{t+2}}{1+\eta_{t+2}}-\gamma_{2} \frac{C F_{t+2}}{K_{t+1}} \frac{\eta_{t+1}}{1+\eta_{t+1}} \\
& -\gamma_{3} \frac{C F_{t+1}}{K_{t}} \frac{\eta_{t}}{1+\eta_{t}},
\end{aligned}
$$

and so on. Given a baseline path for $\mathrm{CF} / \mathrm{K}$ and $\mathrm{g}$, these equations allow us to recursively compute all values of $\eta_{t+\tau}$. The elasticity of the capital stock is then given by $100^{*} \eta_{t+\tau}$. The elasticity of investment can be easily extracted from that of capital. If we define $\eta^{I}{ }_{t+\tau} \equiv \frac{I_{t+\tau}^{s}-I_{t+\tau}}{I_{t+\tau}}$, then, using the capital accumulation equation, we come up with $\eta^{I}{ }_{t}=\eta_{t} \frac{K_{t}}{I_{t}}$ for period $\mathrm{t}$, and $\eta^{I}{ }_{t+\tau}=\eta_{t+\tau} \frac{K_{t+\tau}}{I_{t+\tau}}-(1-\delta) \eta_{t+\tau-1} \frac{K_{t+\tau-1}}{I_{t+\tau}}$ for all later periods. To use these equations we need the baseline paths for $\frac{K_{t}}{I_{t}}$, and $\frac{K_{t+\tau-1}}{I_{t+\tau}}$ as well as the 
values of the depreciation rate. To keep the calculations as simple as possible we have assumed all these variables to be constant. To recover $\delta$, we have used the following identity $\delta=\frac{I_{t}}{K_{t-1}}-g$

where $g$ is assumed to be equal to the average growth of sales in each country; given $\delta$ we then have:

$$
\frac{K_{t}}{I_{t}}=(1-\delta) \frac{K_{t-1}}{I_{t}}+1
$$

We have also used the baseline path of $\mathrm{CF} / \mathrm{K}$ to be the sample average of this variable in each country. Consider now a $1 \%$ shock to cash flow. In period t we will have:

$$
g_{t}^{s}-g_{t}=\gamma_{1}\left(\frac{C F^{s}{ }_{t}}{K_{t-1}}-\frac{C F_{t}}{K_{t-1}}\right)=0.01 \gamma_{1} c_{t},
$$

where $c=\mathrm{CF} / \mathrm{K}$. In period $\mathrm{t}+1$ it will be:

$$
\begin{aligned}
& g_{t+1}^{s}-g_{t+1}=\alpha_{1}\left(g^{s}{ }_{t}-g t\right)+\gamma_{1} c_{t+1} \frac{\left(0.01-\eta_{t}\right)}{\left(1+\eta_{t}\right)}+0.01 \gamma_{2} c_{t}, \\
& g_{t+2}^{s}-g_{t+2}=\alpha_{1}\left(g^{s}{ }_{t+1}-g_{t+1}\right)+\alpha_{2}\left(g^{s}{ }_{t}-g_{t}\right)+\gamma_{1} c_{t+2} \frac{\left(0.01-\eta_{t+1}\right)}{\left(1+\eta_{t+1}\right)}+\gamma_{2} c_{t+1} \frac{\left(0.01-\eta_{t}\right)}{\left(1+\eta_{t}\right)}+0.01 \gamma_{3} c_{t}
\end{aligned}
$$

and so on. We assume that $c$ remains constant in the baseline path. 


\section{REFERENCES}

Arellano, M, and Bond, S. (1991): "Some Tests of Specification for Panel Data: Monte Carlo Evidence and an Application to Employment Equations," Review of Economic Studies, 58, 277-297.

Auerbach, A.J. (1983): "Taxation, Corporate Financial Policy and the Cost of Capital". Journal of Economic Literature, Vol. 21, 905-40.

Banco de España (2000): "Results of Non-Financial Corporations. Annual Report 1999", Central Balance Sheet Office, Banco de España.

Bond, S., Elston, J., Mairesse, J. and Mulkay, B. (1997): “A Comparison of Empirical Investment Equations using Company Panel Data for France, Germany, Belgium and the UK", NBER Working Paper No.5900.

Butzen, P., Fuss, C. and Vermeulen, P. (2001): "The Interest Rate and Credit Channel in Belgium: an Investigation with Micro-Level Firm Data". ECB Working Paper No.107.

Chatelain, J.B. and Tiomo, A. (2001): "Investment, the Cost of Capital and Monetary Policy in the Nineties in France: A Panel Data Investigation". ECB Working Paper No. 112

Chirinko, R., Fazzari, S. and Meyer A. (1999): "How Responsive is Business Capital Formation to its User Cost? An Exploration with Micro Data", Journal of Public Economics, $74,53-80$.

Cummins, J., Hassett, K. and Hubbard, G. (1994): “A Reconsideration of Investment Behavior using Tax Reforms as Natural Experiments", Brookings Papers on Economic Activity, 2, 1-60.

Cummins, J., Hassett, K. and Hubbard, G. (1996): “Tax Reforms and Investment: a Crosscountry Comparison", Journal of Public Economics, 62, 237-273.

Deutsche Bundesbank (1998): "The Methodological Basis of the Deutsche Bundesbank's Corporate Balance Sheet Statistics", Monthly Report, October, 49-64.

Eisner, R. and Nadiri, M. (1968): "Investment Behavior and the Neo-Classical Theory", The Review of Economics and Statistics, 50, 369-382.

Fazzari, S., Hubbard, G. and Petersen, B. (1988): "Financing Constraints and Corporate Investment", Brookings Papers on Economic Activity, 1, 141-206.

Friderichs, H., and Sauvé A. (1999): “The Annual Accounts Databases on Non-Financial Enterprises of the Banque de France and the Deutsche Bundesbank: Methodological Aspects and Comparability", in: Sauvé, A, and Scheuer, M. (eds.), "Corporate Finance in Germany and France" (Deutsche Bundesbank, 1999), 33-62.

Gaiotti, E, and Generale, A (2001): "Does Monetary Policy Have Asymmetric Effects? A Look at the Investment Decisions of Italian Firms". ECB Working Paper, No.110. 
Gilchrist, S. and Zakrajsek, E. (1995): "The Importance of Credit for Macroeconomic Activity: Identification through Heterogeneity", in Peek, J. and Rosengreen, E., "Is Bank Lending Important for the Transmission of Monetary Policy?"

Guiso, L., Kashyap, A., Panetta, F., and Terlizzese, D. (1999), "Will a Common European Monetary Policy have Asymmetric Effects?", Federal Reserve Bank of Chicago Economic Perspectives, 23(4), 56-75.

Hall, B.H., Mairesse, J. and Mulkay, B. (1999): "Firm-Level Investment in France and the United States: an Exploration of What we Have Learned in Twenty Years", Annales d'Economie et de Statistique, 55-56.

Hall, B.H., Mairesse, J. and Mulkay, B. (2001): "Investissement des Entreprises et Contraintes Financières en France et aux Etats-Unis", Economie et Statistique, 341-342, 6784.

Harhoff, D. and Ramb, F. (2001): "Investment and Taxation in Germany: Evidence from Firm-Level Panel Data", in Investing Today for the World of Tomorrow, Deutsche Bundesbank (ed.), Berlin, Heidelberg, New York: Springer

Hayashi, F (2000): "The Cost of Capital, Q, and the Theory of Investment" in Econometrics and the Cost of Capital, Lawrence J. Lau (ed.), The MIT Press, 55-83.

Hsiao, C. (1986): "The Analysis of Panel Data". Cambridge: Cambridge University Press.

von Kalckreuth, U. (2001): "Monetary Transmission in Germany: New Perspectives on Financial Constraints and Investment Spending". ECB Working Paper No.109.

King, M. (1977): Public Policy and the Corporation. London: Chapman and Hall.

King, M. and Fullerton, D. (ed.) (1984): The Taxation of Income from Capital. A Comparative Study of the United States, the United Kingdom, Sweden and West Germany. Chicago and London, The University of Chicago Press.

Lünnemann, P. and Mathä, T. (2001): "Monetary Transmission: Empirical Evidence from Luxembourg Firm Level Data". ECB Working Paper, No.111.

Mankiw, G. and Summers, L. (1988): "Money Demand and the Effects of Fiscal Policies: a Reply", Journal of Money, Credit and Banking, 20, 714-717.

Mairesse, J., Hall, B.H., and Mulkay, B. (2000): "Firm-Level Investment and R\&D in France and the United States: A Comparison", Annales d'Economie et de Statistique, $55-$ 56.

Mojon, B., Smets F., and Vermeulen, P. (2001): "Investment and Monetary Policy in the Euro Area". ECB Working Paper No. 78.

Nickell, S. (1981): "Biases in Dynamic Models with Fixed Effects”, Econometrica, 54, 1417-1425.

Schiantarelli, F. (1995): "Financial Constraints and Investment: a Critical Review of Methodological Issues and International Evidence", in Peek J. and Rosengreen, E. "Is Bank Lending Important for the Transmission of Monetary Policy?" 
Stöss, E. (2001) "Deutsche Bundesbank's Corporate Balance Sheet Statistics and Areas of Application". In Schmollers Jahrbuch (Journal of Applied Social Science Studies), 121. 131-137.

Valderrama, M. (2001) "Credit Channel and Investment Behavior in Austria: A Microeconometric approach". ECB Working Paper No.108. 